University of the Pacific

Scholarly Commons

2003

\title{
Nietzschean Critique and Philosophical Hermeneutics
}

Francis J. Mootz III

University of the Pacific, McGeorge School of law, jmootz@pacific.edu

Follow this and additional works at: https://scholarlycommons.pacific.edu/facultyarticles

Part of the Jurisprudence Commons, and the Other Philosophy Commons

\section{Recommended Citation}

Francis J. Mootz III, Nietzschean Critique and Philosophical Hermeneutics, 24 Cardozo L. Rev. 967 (2003).

This Article is brought to you for free and open access by the McGeorge School of Law Faculty Scholarship at Scholarly Commons. It has been accepted for inclusion in McGeorge School of Law Scholarly Articles by an authorized administrator of Scholarly Commons. For more information, please contact mgibney@pacific.edu. 


\title{
NIETZSCHEAN CRITIQUE AND PHILOSOPHICAL HERMENEUTICS
}

\author{
Francis J. Mootz III*
}

Legal practice naturally invites hermeneutical analysis. Lawyers and judges spend much of their time interpreting authoritative legal texts within the context of evolving social settings that also must be interpreted. In his masterwork, Truth and Method, ${ }^{1}$ Hans-Georg Gadamer argues that legal practice has exemplary significance for hermeneutical philosophy, but he moves well beyond the now commonplace recognition that legal actors must interpret texts and social contexts. His "philosophical hermeneutics" challenges the traditional account of a selfpossessed subject bringing her exegetical prowess to bear on distinct objects that suffer her interpretation. Gadamer rehabilitates practical philosophy by arguing that understanding involves a prudential application of the tradition to the demands of the present, but he radicalizes this account. Gadamer emphasizes that an interpreter is drawn into an event of interpretation in

\footnotetext{
* Professor of Law, Penn State University, Dickinson School of Law. Parts of an earlier draft of this paper were presented at the Fourth Annual Meeting of the Working Group on Law, Culture and the Humanities, convened at the University of Texas in March, 2001; at the Annual Meeting of the Law and Society Association, convened at the Central European University in Budapest, Hungary in July, 2001; and at the conference symposium on Nietzsche and Legal Theory, convened at the Benjamin N. Cardozo School of Law in October, 2001. I am indebted for the many helpful comments and suggestions received from audiences along the way, and in particular I acknowledge the assistance provided by Peter Fitzpatrick, George Taylor, and Victor Romero. I also was fortunate to have the generous support of Dean Peter Glenn and the Law School, both with respect to my research activities and my travel, which permitted me to develop this article.

1 See HANS-GEORG GADAMER, TRUTH AND METHOD (Joel Weinsheimer \& Donald G. Marshall trans., Crossroad, 2d rev. ed. 1989) (1960). Specifically, Gadamer believes that legal practice has exemplary significance for the second of his three principal topics: the historicity of all understanding. Gadamer argues that to understand at all is to understand differently, because understanding always involves an application of preunderstandings to present circumstances and questions. This reality is particularly revealed in the dynamic of adjudication, in which the governing rule is always in flux as it is applied to new situations.
} 
which her own horizon of understanding also is put at risk and reconfigured. Interpretation, Gadamer famously argues, is a fusion of horizons, in which the interpreter and the tradition enter a relationship that has the structure of a dialogue-a playful giveand-take-with the result that the interpreter and the tradition are mutually transformed to some degree. Philosophical hermeneutics challenges methodological approaches to interpretation by claiming that genuine understanding is possible only when the interpreter risks her prejudiced horizon of preunderstanding in dialogic experience.

The epistemological and ontological implications of Gadamer's philosophical hermeneutics are profound. When brought to bear against the naturalism of religious fundamentalists who posit absolute moral principles that transcend individual interests and desires, philosophical hermeneutics is generally applauded and appears almost trite. However, Jürgen Habermas has led the way in vehemently rejecting Gadamer's excessive zeal in pursuing the hermeneutical turn. In effect, Habermas accuses Gadamer of going "postmodern" while clearing a path through the jungle of modern subjectivism, arguing that Gadamer wholly abandons the Enlightenment commitment to critical rationality in his effort to move beyond subject-centered metaphysics. Habermas agrees that the experience of practical wisdom in the course of conversational give-and-take is an important and unavoidable part of the concrete decision-making of individuals living within a social context, but he insists that the very grounds for morality and legality can and must be clarified and defended philosophically. Put differently, Habermas acknowledges that the defense of reason must be "post-metaphysical," but foresees dire consequences if theorists abandon altogether the Enlightenment commitment to rational reconstruction.

In his recent book, Between Facts and Norms, ${ }^{2}$ Habermas extends his criticism of Gadamer's postmodern hermeneutics to pressing issues in contemporary legal philosophy. Habermas acknowledges that law cannot achieve the principled determinacy of moral truths, but insists that law does rise above the pure historical contingency of shared ethical traditions. ${ }^{3}$ Habermas

\footnotetext{
2 JÜRgen Habermas, Between FACTS AND NORMS: CONTRIBUtions TO A DisCOURSE THEORY OF LAW AND DEMOCRACY (William Rehg trans., MIT Press 1996) (1992).

${ }^{3}$ Habermas argues that the Discourse Principle subtends both law and morality, and therefore that neither can be reduced to the traditionalism of socially-constructed ethical life. Id. at 105. However, Habermas recognizes important distinctions between law and morality. Moral norms are valid if, and only if, they satisfy the Discourse Principle, whereas legal norms also are subject to pragmatic considerations. Id. at 108. Moral norms
} 
begins with the insight that law is Janus-faced, in that it operates between social systems that can be studied scientifically and norms that must be justified philosophically. ${ }^{4}$ Law claims legitimacy by appealing to universality and reason, but in fact it always operates in particular social settings and within institutional constraints that lend a high degree of certainty to its operations. ${ }^{5}$ Habermas regards Gadamer's conclusion that law is grounded in an artful development of a living tradition to be dangerous. This is because we no longer have recourse to a thick tradition of substantive reason that is carefully developed through the rhetorical elaboration of shared topoi. Arguing that tradition cannot bear the substantive weight that Gadamer places on it, Habermas underwrites the universal aspirations of law with "communicative reason," which operates as a "weak transcendental necessity" that generally orients us to validity claims even if it cannot specify applicable substantive norms in a particular legal dispute. ${ }^{6}$ By reconstructing the operation of communicative reason in legal discourse, Habermas explains, philosophers can articulate a "critical standard, against which actual practices - the opaque and perplexing reality of the constitutional state-[can] be evaluated." In our post-traditional and post-metaphysical age, we can avoid postmodern chaos only if philosophers uncover the communicative rationality that subtends hermeneutical practices. In short, Habermas believes that critical theory is the only antidote to the multicultural dissolution of lifeworld cohesion.

In a series of articles, I have defended Gadamer's hermeneutical insights and rejected Habermas's commitment (however chastened) to the philosophical goals of the Enlightenment, and I will not rehearse my argument in detail. ${ }^{8}$

bind the individual internally and absolutely, whereas legal norms are pragmatically restricted to governing external relations between citizens in restricted ways. $I d$. at 112 . Finally, the pragmatically limited scope of legal norms has the important effect of reducing the cognitive uncertainty that an individual encounters in trying to discern relevant moral norms. In other words, legal norms are more readily accessible and certain in their application. Id. at 114-17.

${ }^{4} \mathrm{Id}$. at 21 . Habermas uses a series of revealing metaphors, describing law as a "hinge," "transmission belt" and "transformer" between modern social systems and the lifeworld. Id. at 76-81.

${ }^{5}$ Habermas describes the challenge of adjudication as mediating the tension between laws as social facts and laws as norms that promote justice. Id. at 194-237.

${ }^{6}$ Id. at $4-5$.

7 Id. at 5 .

${ }^{8}$ For my analysis of the Gadamer-Habermas debate, see Francis J. Mootz III, The Ontological Basis of Legal Hermeneutics: A Proposed Model of Inquiry Based on the Work of Gadamer, Habermas, and Ricoeur, 68 B.U. L. REV. 523, 568-96 (1988); Francis J. Mootz III, Psychotherapeutic Practice as a Model for Postmodern Legal Theory, 12 YALE J.L \& HUMAN. 299, 306-40 (2000). For my general account of the significance of Gadamer's 
Generally speaking, I am persuaded by Gadamer's rejection of Habermas's attempts to go behind fluid hermeneutical practices in order to identify an abiding, stable and justificatory ground for those practices. If we recognize that hermeneutical practices cannot claim to be grounded in a univocal natural order in the post-metaphysical age, it seems equally clear that we cannot save the day by replacing metaphysical guarantees with Habermas's quasi-transcendental conception of "communicative reason." For present purposes it is sufficient to begin with my commitment to Gadamer's radically postmodern attack on Habermas's residual rationalism. The problem at hand is to investigate where Gadamer leads us.

Even if I am correct that Gadamer "wins" his debate with Habermas by demonstrating that Habermas's critical theory remains trapped within the metaphysics of universal principles and grand narratives, it does not follow that Gadamer has successfully answered Habermas's critique. Gadamer is obligated to provide a detailed response to Habermas's charge that Gadamer's philosophy leads to political conservatism and the abandonment of traditions of philosophical practice that have helped to instantiate reason in social institutions. Gadamer cannot meet this obligation solely by issuing his own challenge to Habermas's postmetaphysical critique. Gadamer would concede that it is highly implausible to reject out of hand any manner of critical theory, and he never makes such a broad claim in his debate with Habermas. Although Gadamer is unclear about the status of critical theory in his philosophical hermeneutics, my thesis is that Gadamer's philosophical hermeneutics legitimates critical theory sufficiently to respond to the accusation that he promotes traditionalism and quietism. Under my reading, Gadamer's philosophical hermeneutics holds the most promise for developing a postmodern critical hermeneutics.

My strategy for drawing a hermeneutical approach to critical theory out of Gadamer's work is to challenge Gadamer by questioning whether philosophical hermeneutics can accommodate Nietzschean critique. If anything can be said of Nietzsche with certainty, it is that Nietzsche was a relentless critic of nearly everything that he saw around him in society. Nietzschean critique is relentless, caustic and seemingly all-encompassing. Nietzschean critique is particularly interesting, though, because it is embedded

philosophical hermeneutics, see Francis J. Mootz III, Law in Flux: Philosophical Hermeneutics, Legal Argumentation, and the Natural Law Tradition, 11 YALE J.L. \& HUMAN. 311 (1999) [hereinafter Mootz, Law in Flux]; Francis J. Mootz III, Rhetorical Knowledge in Legal Practice and Theory, 6 S. CAL. INTERDISC. L.J. 491 (1998). 
in a fundamental attack on the Western metaphysical tradition. Postmodern thinkers generally trace their intellectual debts back to Nietzsche, but Nietzsche stands diametrically opposed to the caricature of a postmodern thinker who is paralyzed by the collapse of metaphysics and therefore incapable of critical theorizing. Consequently, Gadamer's arguments against Habermas's critical theory do not carry much force in response to Nietzschean critique. My thesis is that by understanding how Nietzsche can at once be a critical theorist and a postmodern critic of the metaphysical tradition, we can develop an important resource for articulating the role of critical theory within Gadamer's philosophical hermeneutics. ${ }^{9} \quad$ By exploring the connections between Nietzschean critique and philosophical hermeneutics, I will suggest an affirmative Gadamerian response to the challenges issued by Habermas and other critical theorists.

My argument is organized in five parts. In Part One, I assess Allan Hutchinson's Nietzschean-inspired claim that radical critique in the tradition of the critical legal studies movement provides a necessary antidote to the hermeneutical conventionalism that Gadamer exhibits in his account of law. Having described the challenge posed from within legal theory, in Part Two I develop an account of Nietzschean critique by drawing on recent philosophical reconstructions of his critical activity. I argue that Nietzsche adopts a naturalistic account, but that he characterizes human nature as perspectival and therefore regards critique as a rhetorical activity rather than a demonstrative activity. In Part Three, I build on my model of Nietzschean critique by comparing it with Gadamer's philosophical hermeneutics. I argue that it is productive to read these two philosophers as challenging supplements to one another. In Part Four, I develop my hermeneutical model of Nietzschean critique through a close and critical reading of Gianni Vattimo's nihilistic philosophy, which he derives in large part from Nietzsche. I conclude that Hutchinson's attack on Gadamer's alleged conservatism misses the mark because there is room for Nietzschean critique within philosophical hermeneutics, and that beginning with Gadamer's philosophy accommodates a more satisfactory.account of critique than Hutchinson provides.

I conclude the article by applying my argument to a pressing issue in American life: the legal status of homosexuals. The

${ }^{9}$ I recognize that Nietzsche is an important and interesting thinker for many reasons, and I certainly do not wish to claim that my use of Nietzsche exhausts his relevance for modern thought. My only goal is to establish that he is an important resource for my specific project of defining a critical hermeneutics. 
Supreme Court has addressed this problem in three prominent cases by hermeneutically assessing relevant legal texts and shifting social contexts, but these opinions have been unpersuasive for many observers. Without pretending to provide a single "correct" answer to the issues facing the Court, in Part Five I demonstrate that the Court's opinions fail on simple hermeneutical grounds, and that some form of Nietzschean critique naturally follows in the wake of these hermeneutical failures. I conclude that Nietzschean critique does not contradict the presuppositions of philosophical hermeneutics, but instead works from a shared postmodern account of social reason in a complementary fashion. My aim is to show that Gadamer's philosophical hermeneutics is profitably extended by embracing Nietzschean critique.

\section{THE Demand For RAdiCAl CRitique AS A CHALlenge to HERMENEUTICAL ACCOUNTS OF LAW}

The world of Gadamerian politics is a sterile and barren world in which the material dirt of ideological politics and interests has been washed off so that judges and rhetoricians do not get their hands soiled with life as it is actually lived. But this sanitization misrepresents the grubbiness and messiness of the real social world.

-Allan C. Hutchinson ${ }^{10}$

Critical legal studies, admittedly now a complex and variegated genre, originated with the simple demand by members of the Conference on Critical Legal Studies that rigorous critical theory replace the self-satisfied, incremental development of the legal tradition promoted by the Legal Process school. At the outset, critical legal scholarship primarily aimed to expose contradictions and hypocrisy masquerading as principled legal reasoning, thereby opening the possibility for a more authentic legal practice. An incessant demand for "critique" was a not too surprising feature of this aptly named movement. If "law is politics" was the rallying slogan, then "politics can be critiqued and reconfigured" was the underlying methodological assumption.

The emphasis on politics within critical legal studies is evidenced in the prolific work of Allan Hutchinson. In the mid1980's, Hutchinson-often with co-author Tim Monahan-wrote

${ }^{10}$ Allan C. Hutchinson, Work-In-Progress: Gadamer, Tradition, and the Common Law, 76 CHI.-KENT L. REV. 1015, 1051 (2000). 
passionately about the goals and prospects for critical legal theory. In a review of James Boyd White's literary approach to legal meaning, Hutchinson insists that White's elegant but complacent hermeneutic approach must be replaced with critical insight. White's readings of various historical and legal texts fail because he "ignores the socio-economic determinants of the texts he interprets," and Hutchinson emphasizes that seeking "to understand a text apart from its political history is not only suspicious, but impossible." 11 Hutchinson argues that it is necessary to expose the material determinants of textual meanings - the social, economic, historical and political weight that the text carries-if legal scholarship is to accomplish anything. White's sophisticated, but middle-of-the-road, interpretive approach is dangerous, in Hutchinson's view, because ultimately it leads to one of two equally unsatisfactory results.

First, the interpreter may take the most radical hermeneutic approaches to heart and conclude that texts are nothing but an endless play of words having no fixed meaning. This textual nihilism inevitably devolves into political nihilism because the cultural reproduction that subtends political engagement is regarded as an arbitrary and endlessly malleable event. ${ }^{12}$ Hutchinson cites Sanford Levinson's articles as an example of this tendency to adopt a superficially radical posture that in the end leads to a regressive political paralysis born of a crude nihilism. ${ }^{13}$ Under this nihilistic reading, the hermeneutical dismantling of traditional accounts of language perversely leads to a relapse into a traditionalist politics without utopian aspirations.

The second threat is evidenced by White's work. Having debunked simple-minded traditionalist accounts of language, White responds to the nihilistic abyss by pulling back from the implications of his theory. White offers erudite interpretations that purport to rise above localized contexts, but in fact White unsurprisingly finds that his own prejudiced worldview is confirmed by the texts he chooses to read. Hutchinson charges that "by seeming to discover [humanistic] values embedded in the texts, he naturalizes and universalizes his own preferred set of

11 Allan C. Hutchinson, From Cultural Construction to Historical Deconstruction, 94 YALE L.J. 209, 221, 223 (1984).

12 Id. at 213. See Allan C. Hutchinson \& Patrick J. Monahan, Law, Politics and the Critical Legal Scholars: The Unfolding Drama of American Legal Thought, 36 STAN. L. REV. 199, 236 (1984) (contending that critical legal studies scholarship runs the risk of becoming frozen by its own critical methods, and noting that "their fledgling attempts at social reconstruction have proven vulnerable to the same Critical sword that they wielded to slay liberalism and Marxism").

13 Hutchinson, supra note 11, at 231-33. 
beliefs as the eternal truths and ideals of cultural life." ${ }^{14}$ Nihilism is thwarted, then, only by an unjustified assertion of authority and univocity. "To hold back the tide of imagined nihilism, pluralists, as White's work evidences, smuggle in personal preference as universal insight." 15

Critical legal studies offers a path between hermeneutical nihilism and White's elegant form of whistling in the dark, Hutchinson contends, because it accepts the historical character of critique without accepting a crude historicism. Hutchinson looks to the innovative work of Roberto Unger as a starting point for developing a viable critical legal theory. Unger proposes a theory of human personality that regards human experience as both context-transcending and socially situated, thereby explaining how legal doctrine is at once socially constitutive and subject to critique. ${ }^{16}$ Hutchinson's goal is to develop a sophisticated explanation of how legal doctrine has real-world, constraining effects that call for political action, while simultaneously describing and exploiting a critical distance that permits us to dismantle ideological constraints without succumbing to the conclusion that all possible social arrangements are equally ideological and therefore no more desirable than present ones. In the end, Hutchinson believes that even Unger's work is too beholden to a naturalistic account of the "context-transcending" features of human existence, leading Hutchinson to fear that Unger also invites nihilism by entirely discounting critical judgment and human agency. ${ }^{17}$

Hutchinson's writings during the early years of critical legal studies clearly articulate the question that continues to confront hermeneutical accounts of law today: if we accept the hermeneutic commitment both to linguistic situated-ness and dialogic free play, how do we avoid the twin dangers of political complacency on one hand, and nihilistic despair on the other? Recently, Hutchinson squarely posed this challenge to Gadamer's philosophical hermeneutics. ${ }^{18}$ Responding to my claim that Gadamer's invocation of Aristotelian natural law at a crucial juncture of Truth and Method appears surprising but nevertheless aptly represents the character of his philosophical hermeneutics, Hutchinson insists that it is precisely this conservative attitude within philosophical

${ }^{14}$ Id . at 223

15 Id. at 228.

16 Id. at 234-35; Hutchinson \& Monahan, supra note 12, at 241.

17 See generally Allan C. Hutchinson \& Patrick J. Monahan, The "Rights" Stuff: Roberto Unger and Beyond, 62 TEX. L. REV. 1477 (1984).

18 See Hutchinson, supra note 10. 
hermeneutics that undermines effective critical theory. Extending his earlier articles, Hutchinson charges that traditional approaches to Gadamer's philosophical hermeneutics are antithetical to critical legal theory, thereby bringing the problem of developing a critical hermeneutics into sharp relief.

In Law in Flux: Philosophical Hermeneutics, Legal Argumentation, and the Natural Law Tradition, ${ }^{19}$ I explain that Gadamer's philosophical hermeneutics reinvigorates the classical natural law tradition that is exemplified in Aristotle's analysis of a dynamic and changeable "natural law" of human affairs. ${ }^{20}$ Working from a model that connects Gadamer's hermeneutics with Chaim Perelman's "new rhetoric," I suggest that the nontheistic natural law philosophies of Lon Fuller and Lloyd Weinreb provide descriptions of the hermeneutical-rhetorical character of legal practice. Far from being retrograde, I argue that these natural law accounts supplement the hermeneutical turn in legal theory. I analyze Justice Souter's concurring opinion in the "right to assisted suicide" cases $^{21}$ as a practical example of the "law-influx" paradox that motivates my attempt to outline a postmodern natural law. Souter draws from Justice Harlan's famous analysis that judges are bounded by tradition but that the "tradition is a living thing," ${ }^{22}$ and he accepts the necessity and responsibility in constitutional adjudication to engage in "reasoned judgment" rather than masking decisionmaking by referring to extratextual

${ }^{19}$ Mootz, Law in Flux, supra note 8.

${ }^{20}$ Gadamer refers to Aristotle's approach in setting up his important claim that legal interpretation has exemplary significance for philosophical hermeneutics. Gadamer writes:

For Aristotle, [the fact that natural law is not timeless and unchanging] is wholly compatible with the fact that it is "natural" law.... [Unlike, for example, traffic regulations, there are] things that do not admit of regulation by mere human convention because the "nature of the thing" constantly asserts itself. Thus it is quite legitimate to call such things "natural law." In that the nature of the thing still allows some room for play, natural law is still changeable.... [Aristotle] quite clearly explains that the best state "is everywhere one and the same," but it is the same in a different way than "fire burns everywhere in the same way, whether in Greece or in Persia."

....

[Aristotle's natural laws] are not norms to be found in the stars, nor do they have an unchanging place in a natural moral universe, so that all that would be necessary would be to perceive them. Nor are they mere conventions, but really do correspond to the nature of the thing-except that the latter is always itself determined in each case [contextually].

GADAMER, supra note 1, at 319-20.

${ }^{21}$ See Washington v. Glucksberg, 521 U.S. 702, $752-89$ (1997) (Souter, J., concurring). The companion case is Vacco v. Quill, 521 U.S. 793 (1997).

22 See Glucksberg, 521 U.S. at 765 (Souter, J., concurring) (analyzing Justice Harlan's famous dissenting opinion in Poe v. Ullman, 367 U.S. 497, 543 (1961)). 
(whether conceptual, historical or normative) absolutes. ${ }^{23}$

Hutchinson's detailed critique of my thesis is premised on the inadequacy of philosophical hermeneutics, at least as promoted by "conservative" theorists, to incorporate the lessons of critical legal theory. Arguing that Gadamer's philosophical insights are uncontroversial to some degree, Hutchinson correctly identifies the issue as being how far to push these insights. ${ }^{24} \mathrm{He}$ recoils from my efforts to link a postmodern reading of Gadamer with certain conceptions of natural law, characterizing it as "wild stuff" and "exactly the wrong way to go" with Gadamer's hermeneutics. ${ }^{25}$ Although Hutchinson agrees that there is much in Gadamer's writings that invites my "conservative" approach, ${ }^{26}$ he contends that Gadamer can be fully radicalized only when we abandon the false hope that there can be "bounded and neutral decisionmaking" and recognize that "it is possible to understand law and adjudication as thoroughly political without recommending its complete abandonment." ${ }^{27}$ When I connect hermeneutical understanding to the reasoned elaboration of shared topoi, Hutchinson charges, I domesticate the more radical hermeneutical insight that we constantly are buffeted by multiple, incommensurable traditions that always require legal actors to make a political decision that cannot be avoided by reverting to a "neutral" methodology of legal decisionmaking.

Hutchinson illustrates his thesis by providing an alternative reading of Justice Souter's opinion in the right to assisted suicide cases. Hutchinson concedes that Souter provides a "jurisprudential tour de force" by openly accepting the nonformalistic character of judicial decisionmaking. In the end, though, Hutchinson argues that Souter hedges his bets by refusing to pursue hermeneutical insights in an "unconditional and uncompromising manner," 28 clinging to the belief "that there is a viable way of resisting the critical claim that 'law is politics'." ${ }^{29}$ In short, Hutchinson criticizes Souter for refusing to acknowledge openly that he is making a political decision about the existence of a right to assisted suicide, and he rejects Souter's attempt to hide behind the false hope that adjudication can proceed as a reasoned

\footnotetext{
${ }^{23}$ Id. at $769-70$.

24 See Hutchinson, supra note 10, at 1043.

25 Id. at 1049 \& n.144. Hutchinson asserts that my attempt is a "vast improvement" on Ronald Dworkin's more traditional approach, but nevertheless I read Gadamer's hermeneutical insights through overly conservative lenses. Id. at 1048

${ }^{26} \mathrm{Id}$. at 1080.

${ }^{27}$ Id . at 1016-17.

28 Id. at 1024

${ }^{29} I d$. at 1031.
} 
and neutral articulation of what the Constitution means in a given case. By choosing to recognize certain strands of our legal tradition, Souter makes quintessentially political decisions that reveal his personal political commitments. Hutchinson concludes that Souter's

refusal to recognize the importance of those political commitments means that [recourse to a supposed unitary legal] tradition loses its vital quality as "a living thing" or, as I put it, a work-in-progress. While Justice Souter, Mootz and others are content to leave the sources and direction of its development to some almost mystical historical volkgeist, I prefer to see it for what it is-a heuristic device that does the bidding, no matter how tentative and provisional, of its social artisans and judicial arbiters. ${ }^{30}$

Hutchinson argues that a radical reading of Gadamer's hermeneutical insights would topple this obeisance to a supposed unitary tradition, and would counsel judges to act "less cowardly" when they marshal the contradictory forces within our multiple, contingent traditions in the service of progressive causes. ${ }^{31}$ Hutchinson's theme is simple: a critical perspective leads to the understanding that all law is politics, and therefore facilitates a more vigorous politics.

Hutchinson's critique motivates my project in this article. He begins his argument by challenging Gadamer from a Nietzschean perspective. He attributes Gadamer's conservative leanings to the "fear that radicality must be synonymous with "the nihilism that Nietzsche prophesied," " but he insists that Gadamer's fear is wholly "unwarranted." ${ }_{32}$ Hutchinson pushes to radicalize

30 Id. at 1071 .

${ }^{31}$ Id. at 1079.

32 Id. at 1017 (quoting GADAMER, supra note 1, at xxxvii). Hutchinson completely misreads Gadamer's text in this particular instance, but I concede that Hutchinson's point is made fairly as to Gadamer's work taken as a whole. In the passage in question, which occurs at the very end of the Foreword to the second edition of Truth and Method, Gadamer is addressing the criticism that his book is too recuperative of tradition and therefore lacks critical bite. Gadamer defends his bias by noting the (then) overpowering influence of techno-scientific consciousness that threatens to destroy any connection with tradition. He writes:

[w] hen science expands into a total technocracy and thus brings on the "cosmic night" of the "forgetfulness of being," the nihilism that Nietzsche prophesied, then may one not gaze at the last fading light of the sun setting in the evening sky, instead of turning around to look for the first shimmer of its return?

GADAMER, supra note 1, at xxxviii. In other words, Gadamer aligns himself with Nietzsche's efforts to overcome the nihilism that is the ultimate product of modern consciousness, and is not in any way impugning Nietzsche for being nihilistic.

Nevertheless, Hutchinson has ample grounds to argue that Gadamer might fear the excesses of Nietzsche's critical approach, and that one of Gadamer's objectives is to avoid the more radical elements of Nietzsche's response to the threats of modern consciousness. In the quoted passage, Gadamer chooses to look back at the fading twilight of 
Gadamer's attack on plain meaning and mechanical decisionmaking, and he regards this radicalization as a prerequisite of political engagement rather than an invitation to political nihilism. Because Hutchinson grounds his critical theory in the gritty political encounters of everyday life, he presents a more pointed challenge to Gadamer's hermeneutics than Habermas's philosophy. Rather than asserting that Gadamer has missed a quasi-transcendental reality that subtends hermeneutical practices, Hutchinson contends that Gadamer backs away from the radical implications that follow from Gadamer's description of these hermeneutical practices. In other words, Hutchinson brings a critical challenge to bear on Gadamer's philosophy in a much more unsettling, Nietzschean manner.

I will argue not only that Gadamer's philosophy can meet the challenge of critical legal theory, but that philosophical hermeneutics provides important guidance for Hutchinson and other critics. In Truth and Method, Gadamer set himself the task of recovering the experience of truth that occurs outside the narrow technical-empirical model of the natural sciences; consequently, the primary thrust of his philosophy is recuperative and restorative. Nevertheless, Gadamer makes clear that recuperation and restoration are critical activities that always hold the potential for a fundamental shift in perspective and thinking. I agree with Hutchinson's efforts to radicalize Gadamer's philosophy in order to compel an admission that "law is politics," but I would respond with a Gadamerian reading that questions whether politics is really as contingent, subject-centered and idiosyncratic as Hutchinson would have it. Nietzsche is the correct focus for an examination of the potential for a critical hermeneutics, but I will demonstrate that Nietzschean critique is better accommodated by Gadamer's philosophical hermeneutics than by the critical legal studies approach adopted by Hutchinson, which ultimately endorses a more subject-driven politics.

\section{Nietzschean CRitique: Ontological Perspectivism AND RHETORICAL KNOWLEDGE}

I caught this insight on the way and quickly seized the rather poor words that were closest to hand to pin it down lest it fly

reasonableness, rather than joining with Nietzsche in anticipating the dawn of a new form of reasonableness. Compare FrIEDrich NiETzSCHE, DAYBREAK (R. J. Hollingdale trans., 1982), with FrIEDRICH NiETzSCHE, Twilight of the Idols, in THE PORTABLE NiETZSCHE (Walter Kaufmann ed. \& trans., 1968). 
away again. And now it has died of these arid words and shakes and flaps in them-and I hardly know any more when I look at it how I could ever have felt so happy when I caught this bird.

Nietzsche is a challenging and enigmatic philosopher who resists easy summarization. Nietzsche scholars vigorously advance contradictory interpretations of his work, making it all the more difficult to define "Nietzschean critique." This situation stems in part from the fact that modern Nietzsche scholarship is indebted both to Martin Heidegger, who argued that Nietzsche's "will to power" represented the culmination of the Western metaphysical tradition, and to Jacques Derrida, who argued that Nietzsche is a pioneer in overcoming the metaphysical tradition. In recent years, philosophers in the analytic tradition have proposed a naturalistic reading of Nietzsche's philosophy that represents a more fundamental challenge to the competing continental approaches. These interpretive disputes cannot be resolved by reading Nietzsche's texts more carefully. Diverse readings of Nietzsche's work inevitably follow from the non-traditional (and often aphoristic) nature of his published works; the cumulative, selfreferential, playful and ironic qualities of his texts; and the extensive notebooks of unpublished writings that are available to scholars. Turning to Nietzsche for philosophical clarification, it would seem, is more than a bit like bungee jumping off a tower in order to ease one's feeling of vertigo.

In light of these complexities, I do not pretend to adjudicate the many contentious battles among Nietzsche scholars with the goal of definitively characterizing Nietzsche's work. I do not have the training and temperament for, nor sufficient interest in, such a curious project. My far more modest, and-dare I say-more Nietzschean, goal is to develop a model of Nietzschean critique that satisfies two requirements. First, the model must plausibly be reconciled with Nietzsche's texts and some of the prominent strands in contemporary secondary scholarship. Second, the model must provide substantial guidance in the project of building a critical hermeneutics that overcomes the facial conservatism of Gadamer's philosophy. I do not presume that my model of Nietzschean critique provides a comprehensive account of the significance that Nietzsche's philosophy holds for legal theory. I claim only that my model of Nietzsche's critical activity provides an important resource for questioning whether hermeneutics can

33 Friedrich NiETzSCHE, ThE GAy SCIENCE Book IV para. 298, at 239 (Walter Kaufmann trans., 1974) [hereinafter NIETZSCHE, THE GAY SCIENCE]. 
accommodate critical theory.

My method for constructing a model of Nietzschean critique is mediative and meliorative, in that I seek to find some common ground in contemporary Nietzsche scholarship. ${ }^{34}$ My model derives from two prominent interpretations of Nietzsche: on one hand, analytic philosophers have characterized Nietzsche as a naturalist whose principal aim is to overcome the metaphysical nonsense embodied in religion and traditional (especially moral) philosophy; on the other hand, continental philosophers have emphasized that Nietzsche regards all knowledge as perspectival, and therefore not reducible to correspondence with an objective, free-standing, natural reality. Naturalism provides Nietzsche with a standard by which to judge the metaphysics of modernity, while perspectivism is the means by which Nietzsche deconstructs the Enlightenment conception of the knowing subject. A complementary reading of these two Nietzschean themes holds the promise of generating a model of critical theory that nevertheless fits comfortably with Gadamer's hermeneutical ontology of understanding.

My model is principally indebted to the Continental readings of Nietzsche by Christoph Cox in Nietzsche: Naturalism and Interpretation $^{35}$ and Wayne Klein in Nietzsche and the Promise of Philosophy, ${ }^{36}$ and also the analytical reading by Steven Hales and Rex Welshon in Nietzsche's Perspectivism. ${ }^{37}$ Each book offers a nuanced and integrative interpretation of Nietzsche, from which I draw the following guiding themes: (1) Nietzsche grounds his critical activity in a naturalistic account, but he regards nature as irremediably perspectival; (2) Nietzsche claims that his critiques are "true" only according to the perspectival ontology and epistemology generated by his naturalistic account; and (3) Nietzsche's critical activity is aesthetic and rhetorical, rather than representational and demonstrative. My model preserves the radical character of Nietzschean critique without surrendering to a simple-minded nihilism that ultimately would eviscerate the critical bite of Nietzsche's work.

${ }^{34} C f$. Fred R. Dallmayr, Critical Encounters: Between Philosophy and POLITICS 14 (1987) (arguing that the competing interpretations of Nietzsche by Heidegger and Derrida are both legitimate interpretations if we regard Nietzsche as being "riveted between conflicting paradigms or modes of discourse," and if we acknowledge that Nietzsche's "post-Cartesian Cartesianism can help illuminate our own intellectual meandering between past and future").

35 CHRISTOPH COX, NiETZSCHE: NATURALISM AND INTERPRETATION (1999).

36 WAyne Klein, NiETZSCHE AND THE PROMISE OF PHILOSOPHY (1997).

37 SteVen D. HALES \& ReX Welshon, Nietzsche's Perspectivism (2000). 


\section{A. Nietzsche's Naturalism: A Perspectivist Ontology}

Nietzsche's virulent attacks on Christianity and metaphysics often are presented in naturalistic terms: he criticizes religion and philosophy for promoting fictions and turning away from real life. Several of Nietzsche's later texts "lend support to the view that Nietzsche essentializes the concept of life in order to employ it normatively as a standard against which different forms of social organization and morality can be measured and judged." 38 When appealing to the natural world as the standard by which to criticize the mystifications of his day, Nietzsche often celebrates the role of the natural sciences in overcoming the false rationality of metaphysics. ${ }^{39}$ In The Antichrist, Nietzsche indicts religion because it obscures reality ${ }^{40}$ and his famous announcement of the "death of God" places man back in the natural world as a creature with no special ontological status. ${ }^{41}$ Nietzsche characterizes the natural "reality" that has been denied by religion and philosophy as "will to power." In Beyond Good and Evil, he insists that "we must beware of superficiality and get to the bottom of the matter, resisting all sentimental weakness" in order to describe the essential characteristics of life; he concludes that "life simply is will to power." ${ }^{42}$ In short, religion and philosophy reject the real world

38 KLEIN, supra note 36, at 148.

39 See Friedrich NietzSche, "Reason" in Philosophy, in Twilight of the Idols, in The PORTABLE NiETzSche (Walter Kaufmann ed. \& trans., 1954) [hereinafter NIETZSCHE, Twilight of the Idols]. Nietzsche mocks the philosophical assumption that the senses deceive us about the nature of the true and abiding world, exempting only Heraclitus from his scorn because Heraclitus trusted his senses when they revealed that reality is "multiplicity and change." Id. paras. 1-2, at 480 . He concludes: "Today we possess science precisely to the extent to which we have decided to accept the testimony of the senses - to the extent to which we sharpen them further, arm them, and have learned to think them through. The rest is miscarriage and not-yet-science. ..." Id. para. 3, at 481 . See also FrIEDRICH NiETZSCHE, We Scholars, in BEYOND GOOD AND EviL para. 204, at 311 (Walter Kaufmann trans., 1966), in which Nietzsche notes the displacement of philosophy by science. Nietzsche suggests that science may be all the more amazing to us because it appears to deliver an unwavering and predictable baseline in the face of the modern recognition of the "fickleness of everything human." NIETZSCHE, THE GAY SCIENCE, supra note 33, Book I para. 46, at 111.

40 FriedRICH NiETzSCHE, The Antichrist para. 15, in THE PORTABLE NiETzSCHE 581-82 (Walter Kaufmann ed. \& trans., 1954) [hereinafter NIETZSCHE, The Antichrist]:

In Christianity neither morality nor religion has even a single point of contact with reality. ... . Once the concept of 'nature' had been invented as the opposite of 'God,' 'natural' had to become a synonym of 'reprehensible': this whole world of [religious] fiction is rooted in hatred of the natural (of reality!); it is the Id. expression of a profound vexation at the sight of reality.

41 COX, supra note 35, at 74-75.

42 Friedrich NiETzSCHE, What is Noble, in BEYOND GOOD AND EvIL para. 259, at 
of nature, which is will to power.

Several analytic philosophers have emphasized that Nietzsche's naturalism undercuts Nietzsche's apparent celebration of radical indeterminacy and the impossibility of truth. ${ }^{43}$ They argue that Nietzsche's naturalism demonstrates that he is a committed realist who regards the techno-empirical sciences as an appropriate means for overcoming the mystifications of religion and philosophy and gaining a better understanding of the real (natural) world. In response to continental philosophers who emphasize Nietzsche's numerous references to the radically interpretive character of life, they argue that Nietzsche's rhetorical excesses must be disregarded as inconsistent, if not incoherent, surplusage. In the end, the narrow analytic reading of Nietzsche paints him as a harbinger of a relentless scientific consciousness that attends only to the real world, which is to say a perceptible and empirical world, and ceases useless speculation about metaphysical truths. ${ }^{44}$

If Nietzschean critique were nothing more than a realist naturalism, his work clearly would have little relevance to the project of defining a critical hermeneutics. However, this narrow reading of Nietzsche's naturalism is accomplished only at the cost of sharply limiting the texts deemed worthy of consideration and disregarding much of the content of those texts. Although supported by textual evidence and certainly plausible, the narrow analytic reading is not compelled. This reading not only cuts against a significant portion of his writing, it also undermines Nietzsche's significance as a serious philosopher who rejected a simple-minded realism but nevertheless found ample resources for vigorous critique. Recent commentators from both the analytic and continental traditions have rejected the narrow analytic reading by re-situating Nietzsche's naturalism in his entire body of work and approaching his philosophy in a broader and more integrative manner. Rather than attempting to "save" Nietzsche from incoherence according to pre-existing realist prejudices, these scholars attempt to understand how Nietzsche's professed

203 (Walter Kaufmann trans., 1966) [hereinafter NIETZSCHE, What is Noble]. See also FRIEDRICH NIETZSCHE, On the Prejudices of Philosophers, in BEYOND GOOD AND EVIL para. 13, at 21 (Walter Kaufmann trans., 1966) (contending that "life itself is will to power" and regarding the claimed instinct for self-preservation as a "superfluous teleological" principle that refers to a frequent result of will to power) and FRIEDRICH NIETZSCHE, The Free Spirit, in BEYOND GOOD AND EVIL para. 36, at 115 (Walter Kaufmann trans., 1966) (essentializing will to power).

${ }^{43}$ Certainly the most prominent example is MAUdEMARIE CLARK, NIETZSCHE ON TRUTH AND PHILOSOPHY (1990).

44 There certainly is textual support for this claim. See, e.g., FRIEDRICH NIETZSCHE, THE GAY SCIENCE, supra note 33, Book IV para. 319, at 253; id. para. 335, at 263. 
naturalism can coexist with his perspectivism. Under their reading, while it is true that Nietzsche criticizes religion and philosophy against the standard of natural reality, Nietzsche regards natural reality as deeply perspectival and interpretive.

Nietzsche's assessment of science is far too ambivalent to compel a realist reading of his naturalism. The emergence of science coincides with the death of God and the movement away from religion, but Nietzsche regards much of modern science as theology by other means. ${ }^{45}$ Rather than overcoming the "ascetic ideal" expressed in the religious and metaphysical retreat from nature, science intensifies the denial of nature by reducing it to objects that have causal-mechanistic relationships open to our perspicacious description. ${ }^{46}$ Nietzsche criticizes the sober realists who believe that the world is arrayed before their detached gaze and who refuse to acknowledge the "secret and inextinguishable drunkenness" of life. ${ }^{47}$ Consequently, Nietzsche regarded the science of his day as the culmination of the Western metaphysical tradition that threatens to bring on a "midnight" of nihilism, but he believed that this, in turn, would set the stage for a new dawn in which we can affirm the death of God rather than seek a surrogate

${ }^{45}$ CoX, supra note 35 , at 16-27.

46 Nietzsche attacks the natural scientists for supposing that their interpretive schemas, in particular causation, are objective features of the real world.

One should not wrongly reify "cause" and "effect," as the natural scientists do (and whoever, like them, now "naturalizes" in his thinking), according to the prevailing mechanical doltishness.... In the "in-itself" there is nothing of "causal connections," of "necessity," or of "psychological non-freedom"; there the effect does not follow the cause, there is no rule of "law." It is we alone who have devised cause, sequence, for-each-other, relativity, constraint, number, law, freedom, motive, and purpose; and when we project and mix this symbol world into things as if it existed "in itself," we act once more as we have always actedmythologically.

FRIEDRICH NIETZSCHE, On the Prejudices of Philosophers, in BEYOND GOOD AND EVIL para. 21, at 29 (Walter Kaufmann trans., 1966) [hereinafter NiETZSCHE, On the Prejudices]. Nietzsche makes this point forcefully in the opening sections of Book Three of The Gay Science. Although God is dead, Nietzsche writes, we must now engage in a new struggle to vanquish his "shadow." NIETZSCHE, THE GAY SCIENCE, supra note 33, Book III para. 108, at 167 . He then cautions against regarding nature as an organism or a machine and asks, "When will all these shadows of God cease to darken our minds? When will we complete our de-deification of nature? When may we begin to "naturalize" humanity in terms of a pure, newly discovered, newly redeemed nature?" Id. para. 109, at 167. Immediately following this question are three sections in which Nietzsche locates the origins of knowledge, logic and causality in error, illogic and flux, id. para. 110, at 169; id. para. 112, at 172, indicating that Nietzsche does not equate nature with the object of modern scientific consciousness. See also id. Book IV para. 300, at 240 (contending that magic, alchemy and astrology are preludes to contemporary science). This is confirmed in Book Five, added in 1887 , in the sections entitled, How we, too, are still pious, and "Science" as a prejudice. Id. Book V para. 344, at 280; Id. para. 373, at 334.

47 NiETZSCHE, THE GAY SCIENCE, supra note 33, Book II para. 57, at 121. 
in science. ${ }^{48}$ This new day would be the advent of the gay science that Nietzsche heralded: a joyous affirmation of the human condition.

Nietzsche grounds his critique in nature, but he rejects the subject/object dualisms that defined the scientific worldview of his day in favor of "will to power,"-the view that all of nature is engaged in ongoing, active interpretation. ${ }^{49}$ Nietzsche proposes a radically new holistic ontology to replace the "theological" ontology of the nineteenth-century natural sciences. ${ }^{50}$ Naturalism and interpretivism coexist, then, by recognizing that:

if will to power is the naturalistic theory par excellence, and if will to power essentially involves interpretation, the naturalist is led to assert the primacy and irreducibility of interpretation.... In short, for Nietzsche, the natural world is fundamentally interpretive. There is no world other than the natural and nothing outside the interpretive web that constitutes this natural world. ${ }^{51}$

Nietzsche never provided a detailed explanation of will to power, but Hales and Welshon argue that an analytic reading of his texts makes clear that he was proposing a radically alternative "perspectivist ontology of power." 52 Under this ontology, humans are not interpretive animals that "create" the world according to their desires, but rather are the most complex beings in a deeply interpretive play of forces that includes all of nature. ${ }^{53}$ Cox concurs:

Against all realisms, Nietzsche maintains that every ontology is

48 COX, supra note 35 , at 27. See also GiAnni VATtimo, Nietzsche: AN INTRODUCTION 43-58 (Nicholas Martin trans., 2001) (1985) (Explaining that Nietzsche challenged the positivist accounts of science at the same time that he acknowledged the powerful effect of science within contemporary culture, leading Nietzsche to adopt more nuanced views that connected the activities of art and science).

${ }^{49} I d$. at 214.

${ }^{50} I d$. at 221.

51 Id. at 241-42. Gianni Vattimo echoes this hermeneutical reading of "will to power": If one may say this, the Will to Power is something hermeneutic, something engaged in interpreting. The struggle between the opposing tendencies of a multiplicity of wills is above all a struggle between competing interpretations, as that fragment concerning European nihilism shows.... Yet the Will to Power is also hermeneutic in another sense: because it sees the world as a game of competing appearances and perspectives, it is itself one theory among others, an interpretation and nothing else. Nietzsche concedes this point explicitly at the end of an aphorism in Beyond Good and Evil: "Assuming this too is only interpretation [.. .] well, so much the better.'” (BGE \$22, 31).

VATTIMO, supra note 48, at 124.

52 HALES \& WELSHON, supra note 37, at 58. Although some analytic commentators choose to ignore the corrupted, posthumous text Will to Power, Hales and Welshon responsibly use the unpublished materials in support of what they find anticipated in his published texts. Id. at 62-63.

53 Id. at 63-65. 
the construction of an interpretation and that no world would remain over after the subtraction of every interpretation.... Nietzsche short-circuits the distinction between idealism and realism by dissolving the poles of subject and object into the unified field of interpretation or will to power. ${ }^{54}$

The perspectival character of will to power is reflected in Nietzsche's thoroughly perspectival accounts of the self ${ }^{55}$ and the world of objects. ${ }^{56}$ These accounts do not devolve into nihilistic relativism precisely because they are so radical. In Nietzsche's account there is no autonomous self who can choose to impose an interpretation as a matter of whim or fancy, since selves always already are the products of and proponents of a thick network of interpretations. ${ }^{57}$

Nietzsche delivers naturalistic critiques of Christianity and metaphysics, but he is criticizing their abandonment of a natural reality that is deeply interpretive. The absolute and binary world proposed by these fables is a complete abstraction from the real world, where knowledge is gained because of, and not in spite of, perspectivity. This point is most clearly expressed by Nietzsche in the celebrated passage from On the Genealogy of Morals, in which he mocks the philosophical manifestation of an ascetic hostility to life: "To cease believing in one's own self, to deny one's own "reality"-what a triumph! ..." In opposition to this ascetic ideal, Nietzsche advocates that philosophers embrace the interpretive character of nature, in order to usher in a new

"objectivity"... understood not as "disinterested

contemplation" (which is a non-concept and a nonsense), but as

54 CoX, supra note 35, at 163.

55

Nietzsche not only views the subject as a multiplicity of micro-interpretations and -perspectives; he also views the subject itself as a macro-interpretation. The point is simply that, for Nietzsche, interpretation goes all the way down and all the way up. Rather than positing the subject as something outside the realm of interpretation, something that stands behind and fabricates interpretations, Nietzsche maintains that the subject itself is fabricated by and as an interpretation. Id. at 138-39.

${ }^{56}$ Nietzsche regards the world of objects as a radical flux of power relations that is channeled by human activities into a manageable reality: "objects are what they are only under a particular description, for a particular perspective or interpretation." Id. at 154 (criticizing the attempt by Brian Leiter and others to portray Nietzsche as a realist).

57 As Cox explains, Nietzsche does not

deny the reality of the external world or claim that we can make interpretations, worlds, subjects, and object any way we please. He understands that there are always constraints upon our worldmaking. He only refuses to grant that there is some pre-given world that can or should ultimately serve as that constraint. Rather, what reality there is and what constraints there are, Nietzsche argues, are provided solely by the dominant, existing interpretations.

Id. at $159-60$ 
the capacity to have all the arguments for and against at one's disposal and to suspend or implement them at will: so that one can exploit that very diversity of perspectives and affective interpretations in the interests of knowledge. From now on, my dear philosophers, let us beware of the dangerous old conceptual fable which posited a "pure, will-less, painless, timeless knowing subject", let us beware of the tentacles of such contradictory concepts as "pure reason," "absolute spirituality," "knowledge in itself"; - for these always ask us to imagine an eye which is impossible to imagine, an eye which supposedly looks out in no particular direction, an eye which supposedly either restrains or altogether lacks the active powers of interpretation which first make seeing into something-for here, then, a nonsense and non-concept is demanded of the eye. Perspectival seeing is the only kind of seeing there is, perspectival "knowing" the only kind of "knowing"; and the more feelings about a matter which we allow to come to expression, the more eyes, different eyes through which we are able to view this same matter, the more complete our "conception" of it, our "objectivity", will be. ${ }^{58}$

The falsifications introduced by the ascetic ideal, as it is manifested in religion, philosophy, and even science, can be overcome only by affirming that perspectivism is the nature of reality.

\section{B. The (Non-Metaphysical) Truth of Ontological Perspectivism}

Nietzsche's naturalism grounds his critique, but by endorsing a perspectival account of nature he courts obvious difficulties. For example, Brian Leiter advances the narrow analytic reading by arguing that a radically perspectivist ontology undermines Nietzsche's claim that his critiques provide epistemically privileged access to reality. ${ }^{59}$ The challenge is straightforward: Nature can't provide a standard against which to judge the metaphysical tradition if nature is merely a contest of perspectives, none of which can claim epistemic superiority by virtue of corresponding more accurately to an independent world. Leiter concludes that we must take Nietzsche's optical analogy in the Genealogy quite literally, which leads him to declare that Nietzsche is a pluralist

58 FRIEDRICH NIETZSCHE, ON THE GENEALOGY OF MORALS Third Essay para. 12, at 98 (Douglas Smith trans., 1996) (1887).

59 Brian Leiter, Perspectivism in Nietzsche's Genealogy of Morals, in NiETzSCHE, GeneAlogy, MORALITY: ESSAyS ON NIETZSCHE'S GENEALOGY OF MORALS 334, 339 (Richard Schacht ed., 1994) (arguing that one can avoid this dilemma only by abandoning Nietzsche's epistemic claims, by reducing them to rhetorical flourish, or (with Leiter) by revising the account of Nietzsche's naturalism to accord with his epistemic claims). 
who nevertheless recognizes an epistemic hierarchy. Leiter argues that our ordinary experience of sight teaches us that there is no single, acontextual, all-encompassing view of an object-the "God's-eye" view from nowhere-but, nevertheless, that some views are better than others, and multiple views of an object are even more likely to yield an accurate conception of that object. ${ }^{60}$ "On this position knowledge is possible, though never complete, and it always requires a plurality of interpretive perspectives." 61 Nietzsche's naturalism is preserved by reading his doctrine of perspectivism as an account of the limitations of human perception and cognition in processing the real world.

Although certainly plausible, this reading is not easily borne out by Nietzsche's texts and is made possible only by virtue of the loaded question to which it responds. Leiter asks whether the "optical situation" referenced by Nietzsche in the Genealogy is more closely analogous to radically perspectivist readings of Nietzsche or to more traditional, neo-Kantian readings of Nietzsche, but he surreptitiously constructs the "optical situation" in a manner that answers the question beforehand. Leiter wrongfully assumes "a pre-given subject who has perspectives or interpretations" of a determinate, pre-given object. ${ }^{62}$ But as explained above, Nietzsche's perspectivist ontology undermines such an account of "ordinary" vision; indeed, that is the very point of his perspectivism. Specifically, Nietzsche embraces a dynamic and interpretive account of supposedly "pure" perception, affirming the deeply constitutive nature of perspectivity. ${ }^{63}$ The

\footnotetext{
${ }^{60}$ Id. at $345-47$.

${ }^{61} I d$. at 351.

62 COX, supra note 35, at 121.

${ }^{63}$ Nietzsche argues that science does not proceed by first acknowledging new perceptions, but that often new perceptions are not possible until after the "rash hypotheses," "fictions," "the good dumb will to "believe'," and "the lack of mistrust and patience" have set the stage. FRIEDRICH NIETZSCHE, Natural History of Morals, in BEYOND GOOD AND EvIL para. 192, at 104-05 (Walter Kaufmann trans., 1966). He
} explains:

Our eye finds it more comfortable to respond to a given stimulus by reproducing once more an image that it has produced many times before, instead of registering what is different and new in an impression. The latter would require more strength, more "morality." Hearing something new is embarrassing and difficult for the ear... Even in the midst of the strangest experiences we still do the same: we make up the major part of the experience and can scarcely be forced not to contemplate some event as its "inventors." All this means: basically and from time immemorial we are-accustomed to lying. Or to put it more virtuously and hypocritically, in short, more pleasantly: one is much more of an artist than one knows.

Id. at 105. In this passage Nietzsche clearly distinguishes perception for sensory stimuli, although he does so in the context of noting the conservatism that follows from our interpretive nature: our prejudiced perceptual forestructure, one might say. See also 
passage from the Genealogy supports this reading, since Nietzsche rejects both the idea that eyes are agents that restrain interpretation, and the idea that eyes are purely passive instruments. Instead, he affirms that the eyes participate in "the active powers of interpretation which first make seeing into something." Moreover, a reasonable reading of Nietzsche's texts supports the conclusion that he makes the doctrine of perspectivism central to his ontology and epistemology. As Hales and Welshon dryly conclude in the course of their analytic reading of Nietzsche, "[i]f the choice is between relying on Nietzsche's Nachla $\beta$ to develop a robust theory of ontological perspectivism or amputating this ontology and turning Nietzsche into a retrograde Kantian, the former is surely preferable." ${ }^{64}$

Leiter promotes the narrow analytic reading because he believes that Nietzsche is too demonstrably committed to the truth of his critiques to endorse a radically perspectivist ontology that would rob his philosophy of a claim to epistemic privilege. But the issue is more complex than Leiter allows, in that it is unnecessary to force a choice between epistemic nihilism and a realist epistemic hierarchy. Hales and Welshon carefully develop the thesis that perspectivism is the core of Nietzsche's philosophy, without concluding that Nietzsche abandons truth claims. They explain that Nietzsche adopts a "weak perspectivism"- -holding only that there are some statements that are true in some perspectives while false in others-rather than a "strong perspectivism"-under which every statement would be true in at least one perspective and false in another. ${ }^{65}$ Consequently, Nietzsche allows that there may be some statements, admittedly not many, that are true "in all human perspectives, statements that are true for all humans no matter what else is true in their perspective." ${ }_{66}$ The crucial point for Nietzsche is that even absolute truths, such as logic or certain causal relationships, are not validated by direct correspondence to

NIETZSCHE, THE GAY SCIENCE, supra note 33, Book III para. 114, at 173-74 (“As soon as we see a new image, we immediately construct it with the aid of all our previous experiences, depending on the degree of our honesty and justice. All experiences are moral experiences, even in the realm of sense perception."). See KLEIN, supra note 36, at 71:

One of the aims of Nietzsche's genealogy of the word is to criticize this naively held belief [that words serve as a neutral medium which mediates our experience of a world of pre-existing and pre-linguistic objects] by demonstrating that even those experiences that we consider most basic, tactile sensation for example, are not immediately given but are always already determined by linguistic structures Id. such as metonymy, metaphor and synecdoche.

${ }^{64}$ Hales \& Welshon, supra note 37 , at 77.

65 Id at 15-36.

66 Id. at 34 . 
a world-in-itself, but instead are only perspectivally true. ${ }^{67}$

Under this reading, then, Nietzsche can claim without selfcontradiction that his perspectivist ontology - designated as will to power-is true, even that it is absolutely true. In other words, Nietzsche can plausibly advance a thesis of ontological perspectivism at the same time that he insists on epistemological perspectivism. $^{68}$

Hence, perspectivist ontology can be absolutely true, if we are careful to insist that an absolute truth is a truth across, rather than outside of, human perspectives. So, perspectivist ontology can be absolutely true even though weak perspectivism is true of many other sentences. So, given that the version of perspectivism attributable to Nietzsche is weak perspectivism and the relevant perspectives are human perspectives, there is no self-referential inconsistency between the absolute truth of perspectivist ontology and alethic perspectivism. ${ }^{69}$

Perspectivism provides an ontological account that is true in all human perspectives, just as the principles of logic or the laws of

67 "It is precisely extra-perspectival truth and non-truth that Nietzsche ridicules and rejects outright: no matter how essential a belief is for the preservation and enhancement of life-no matter even if it is absolutely true - it still is not extra-perspectivally true." Id. at 35. For example, Nietzsche's critique of logic is not that logic is not absolutely true, but only that we misread the logic that girds our grammar by hypothesizing a full-blown realist metaphysics that posits objective entities. Id . at 37-56. Similarly, Nietzsche's critique of causality is not intended to deny certain realities that he designates as will to power, but rather to tear down the reification of mechanical causes and effects as perspectiveindependent laws that take God's place. Id. at 85-110.

Gianni Vattimo makes this same point in connection with Nietzsche's critique of morality as the sublimation of all too human factors, arguing that Nietzsche's apparent claim to uncover what is really going on can be read consistently with his deconstructive critique.

To detect something like a "drive to preservation" or "the intention to achieve pleasure" at the root of morality is not the same as identifying the source of a moral value in stable, fixed structures of Being-in other words in those structures which since time immemorial have provided traditional metaphysical or religious morality with a justification for its prescriptive systems. The "drive to preservation" and "the intention to achieve pleasure" are malleable forces which permit us to view morality as a diachronic process.

VATTIMO, supra note 48 , at 65.

${ }_{68}$ Hales and Welshon explain the difference between these epistemological perspectivism and ontological perspectivism:

According to epistemological perspectivism, objective knowledge is vitiated by the perspectivity of epistemic capacities and the perspectival constitution of the object of knowledge. Ontological perspectivism claims that there are no facts in the world to which ideas and propositions could possibly correspond, even if, counterfactually, epistemic capacities were not perspectival. Since each quantum of will to power is a perspective and perspectives are loci of interpretation, there exists nothing but loci of interpretation, and hence it is not possible that there be an interpretation-independent world.

HALES \& WELSHON, supra note 37, at 202.

${ }^{69}$ Id. at 199. 
causation are absolutely true, but the truth of Nietzsche's ontology is not established by its correspondence with a perspectiveindependent world, for no such world exists.

Wayne Klein proposes a similar, although less satisfactory, solution to the alleged incoherence in Nietzsche's philosophy. Klein emphasizes that Nietzsche's critique of morality is not undermined by his critique of truth for the simple reason that Nietzsche does not reject truth but instead undertakes a radical reinterpretation of truth. ${ }^{70}$ "What is being denied-if one wishes to employ this vocabulary-is the coherence of the correspondence theory of truth, not the concept of truth itself." ${ }^{\prime 1}$ Truth is secured with a genealogical inquiry rather than by assuring the correspondence of statements with objective reality. Ultimately, Klein suggests that Nietzsche's "will to power" is not an essentialist account of nature, but instead is offered as a genealogical interpretation of nature. ${ }^{72}$ Klein's approach tends to undermine Nietzsche's claim to be offering a valid interpretation of the cultural and intellectual situation in which he found himself, although it is certainly correct to characterize Nietzsche's naturalism as an "interpretation" to the extent that Nietzsche argues that nature is perspectival. ${ }^{73}$ Hales and Welshon carefully demonstrate how Nietzschean critique can consistently claim to be more than just another interpretation offered to a chaotic marketplace of ideas, and thus their approach provides a more integrative account that respects Nietzsche's assertions of truth.

There is a reasonable solution to the apparent contradiction between Nietzsche's claim that his perspectivist ontology of "will to power" is true and can serve as a standard against which to criticize social institutions and traditions, and his claim that all

70 KLEIN, supra note 36 , at 59-60.

${ }^{71} \mathrm{Id}$. at 74 .

72 Id. at 156 (characterizing "will to power" as "one way among others of describing nature, a form of description that Nietzsche recognizes as explicitly metaphorical").

${ }^{73}$ Klein correctly contextualizes Nietzsche's various essentialist claims about "will to power" in Beyond Good and Evil by referring to an early section in which Nietzsche challenges those who would draw democratic lessons from "nature." Id. at 151-56. Nietzsche suggests that this "interpretation" of nature is easily countered by an account of nature as "will to power," and that will to power might also mean that the world "has a 'necessary' and 'calculable' course, not because laws obtain in it, but because they are absolutely lacking, and every power draws its ultimate consequences at every moment." NiETzsCHE, On the Prejudices, supra note 46, para. 22, at 30-31. By positing will to power as an alternate interpretation, Nietzsche invites the obvious question: "Supposing that this also is only interpretation-and you will be eager enough to make this objection?-well, so much the better." Id. But acknowledging that his ontology is an interpretation is not tantamount to acknowledging that it has the same truth status as any other interpretation. Klein's rhetorical reading of Nietzsche, which effectively corrects the apparent slide to nihilism, is discussed in the next section. 
knowledge and truth is perspectival. Commentators generally have given emphasis to one of these claims in an effort to eliminate the charge that Nietzsche cannot press both claims without being incoherent. On one hand, Hales and Welshon agree with Maudemarie Clark that Nietzsche is not a nihilistic relativist, but they disagree with her strategy (followed by Leiter) of watering down Nietzsche's epistemological perspectivism to a minimalist correspondence theory of truth in order to make his theory consistent. ${ }^{74}$ On the other hand, they also reject John Richardson's solution of construing Nietzsche's ontological claims as potentially being false in some perspectives in order to preserve his perspectival epistemology without contradiction. ${ }^{75}$ The paradox of Nietzsche's thoroughgoing perspectivism serving as the standard for his naturalistic critiques turns out to be a comprehensible and comprehensive reading of Nietzsche's philosophy. Put more forcefully by Christoph Cox, Nietzsche's naturalism and perspectivism can stand only if they stand together, because they supplement and qualify the tendency to excess that each doctrine invites. ${ }^{76}$

\section{Nietzschean Critique as an Aesthetic and Rhetorical Practice}

Even if it is plausible and coherent to characterize Nietzschean critique as a practice of criticizing cultural phenomenon against the standard of our "perspectival nature," substantial difficulties remain. It is not clear that Nietzsche has successfully identified a standard for discriminating between competing critical interpretations that claim to uncover a naturalistic standard for critique that is true across human perspectives. For example, when a religious fundamentalist criticizes the emergence of gay rights as a decadent affront to man's heterosexual "nature," is the fundamentalist's critique epistemologically equivalent to Nietzsche's perspectivist ontology and his resulting critique of religion? If so, critical inquiry is overcome by the relativism that Nietzsche clearly rejected. It is no

\footnotetext{
74 HALES \& Welshon, supra note 37, at 192-93.

75 Id. at $193-95$.

76

Taken together, these doctrines tread between relativism and dogmatism without yielding to either extreme. The apparent relativism of perspectivism is held in check by Nietzsche's naturalism, which offers the doctrines of will to power and becoming in place of all theological interpretations... yet ones that are better by naturalistic methods.

COX, supra note 35, at 106.
} 
answer to state that Nietzsche prevails in this dispute because he works from man's perspectival nature rather than from metaphysical and religious myths, because the fundamentalist is putting into question the presumption that Nietzsche's ontology and epistemology are the appropriate standard. The fundamentalist appeals to the (divinely-ordered) world-in-itself and sees no need for argumentation. In contrast, Nietzsche's perspectival ontology appears to preclude him from successfully rebutting fundamentally inconsistent naturalistic accounts, including religiously-inspired natural law theories.

These questions bring us to the heart of Nietzschean critique. Nietzsche's genealogical interpretation of human nature is rhetorical rather than demonstrative; he argues about matters that lend themselves only to probabilities rather than definitive resolution. Nietzsche cannot compel the religious fundamentalist to accept his perspectivist ontology, but this is not worrisome to Nietzsche since he is arguing that things couldn't be otherwise. ${ }^{77}$ His goal is to persuade rather than to dictate, and persuasion is a function of what traditionally would be designated as mere style. By cajoling his readers to take his destabilizing critiques seriously, Nietzsche invites them to risk loosening their metaphysical prejudices. If another philosopher pulls with equal vigor in a different direction, so much the better, for it is in the weighing and consideration of different perspectives that one can genuinely experience the perspectivity of nature.

Modern thinking discounts the cogency of rhetorical persuasion, but Nietzsche's perspectival ontology and epistemology lead him to embrace the "dangerous maybe" of rhetorical argumentation. ${ }^{78} \quad$ A religious fundamentalist and Nietzsche offer competing interpretations and critiques, but Nietzsche's perspectivist account does not force him to concede that these critiques are equally legitimate. In rhetorical

77 As Nietzsche aptly puts the point, we "cannot look around our own corner: it is a hopeless curiosity that [seeks to rise above one's perspective to clearly see perspectivity itself]. But I should think that today we are at least far from the ridiculous immodesty that would be involved in decreeing from our corner that perspectives are permitted only from this corner." NIETZSCHE, THE GAY SCIENCE, supra note 33, Book V para. 374, at 336.

78 NietzsCHE, On the Prejudices, supra note 46, para. 2, at 10. Nietzsche criticizes the absolutism of Platonic metaphysics for refusing to accept a naturalistic explanation of truth as arising out of, and intertwined with, deception. Id. He heralds the new philosophers who are willing to ask whether the value of truth is "insidiously related, tied to, and involved with these wicked, seemingly opposite things-maybe even one with them in essence. Maybe!" Id. This "dangerous maybe" represents a willingness to break from bivalent thinking, to move beyond good and evil, and to embrace the realm of rhetorical engagement that deals only with probabilities. See Douglas ThOMAS, READING NIETZSCHE RHETORICALLY $72-77$ (1999). 
engagement, competing interpretations are weighed in a manner that can yield a provisional conclusion that one is a better interpretation. Nietzsche's works represent an extended rhetorical appeal that claims to be a better interpretation, all the while admitting that there can be no final demonstration of truth by an appeal to correspondence with the "world-in-itself." Nietzsche does not surrender to epistemological relativism, nor does he seek comfort in epistemological dogmatism. He contends that knowledge can emerge from rhetorical engagements, but that there is no determinant methodology that can compel recognition of the victorious argument. ${ }^{79}$ This is why Nietzsche repeatedly bemoans the "herd mentality" that renders so many people deaf to his message. ${ }^{80}$ Like any rhetorician, he can be persuasive only when the audience is prepared to hear his message. In his caustic indictment of Christianity in The Antichrist, Nietzsche begins by acknowledging that the "book belongs to the very few. Perhaps not one of them is even living yet." 81 In light of his radical reworking of the philosophical tradition, Nietzsche appears to accept his fate as a posthumous philosopher. ${ }^{82}$

Klein's concession that Nietzsche "merely" offers a competing ontological interpretation must be read in the context of Klein's emphasis on the rhetorical dimension of Nietzsche's project. Hales and Welshon demonstrate that Nietzsche can consistently assert absolute truths, but Klein makes clear that these assertions are rhetorical, and therefore never absolutely immune against the

79

Nietzsche is not interested in providing a theory of truth, then, because truth is not something that admits of final determination by a fixed set of criteria. Truth is the fleeting calm between battles within a war that has no preordained or final victor. What does interest Nietzsche, however, is ensuring that the struggle continue and that inquiry not come to an end with the enforced peace of dogmatism.

Cox, supra note 35 , at 61 .

${ }^{80}$ Nietzsche's texts are replete with references to the great majority that is unprepared for his message, many of them rather brutal and condescending. In concluding the Preface to The Antichrist Nietzsche catalogues the qualities that his readers must display to understand his work and then asks, "what matter the rest? The rest-that is merely mankind. One must be above mankind in strength, in loftiness of soul-in contempt." NiETzSCHE, Preface to The Antichrist, supra note 40. In the course of arguing that it is necessary to move "beyond good and evil," Nietzsche repeatedly notes the inability of most people to understand the radical nature of his message. FRIEDRICH NIETZSCHE, BEYOND GOOD AND EVIL para. 14, at 21 (Walter Kaufmann trans., 1966); id. para. 62, at 74-76; id. para. 202, at 115; id. para. 203, at 117; id. para 212, at 137-39.

81 NiETZSCHE, Preface to The Antichrist, supra note 40.

${ }^{82}$ But the provocation of his critiques, even if not fully understood by his contemporaries, serves a preparatory purpose. "Posthumous men-I, for example-are understood worse than timely ones, but heard better. More precisely: we are never understood-hence our authority." NIETZSCHE, Maxims and Arrows para. 15, in Twilight of the Idols, supra note 39 , at 468. 
challenges of interlocutors. Klein argues that even Nietzsche's apparently relativistic challenge to the concept of truth, On Truth and Lies in the Extra-Moral Sense, must be read in the light of lecture notes for a course on rhetoric that Nietzsche prepared in the same year. ${ }^{83}$ Nietzsche does not reject truth entirely, but instead looks to the ancient tradition of rhetoric as a guide for claiming truth as to matters that admit only of probabilities. Klein's rhetorical reading buttresses the conclusion reached by Hales and Welshon about Nietzsche's perspectivist approach to knowledge, for it is in rhetorical engagement that Nietzsche claims that his perspectivist ontology is absolutely true. Hales and Welshon write: "If there is no absolute knowledge in most of the sense that can reasonably be assigned to that phrase, the appropriate response is 'so what?' There is still knowledgerobust, honest, decent, genuine, perspectival knowledge. And, says Nietzsche, this is all we really need." ${ }^{\prime 4}$ Perspectival truth is the product of rhetorical engagement, but it is sufficient as truth even if it doesn't meet the false hopes of extra-perspectival knowledge.

Nietzsche's rhetorical conception of truth and argumentation is not systematically described in his writings. The best evidence of his rhetorical philosophy is to consider his writings as exemplifying the rhetorical activity to which he refers. As Douglas Thomas puts it, Nietzsche "rethinks philosophy through rhetoric." 85 Commentators have made much of Nietzsche's unconventional style of writing, sometimes suggesting that his works are more literary than philosophical. But this misses the rhetorical depth of Nietzsche's philosophy: "Nietzsche's understanding of interpretation, which is fundamentally set against Platonism, can and should be read as a rhetorical system of thought which, ultimately, effects a return to style as a constitutive element of representation itself." 86 Style is not merely ornamentation, but instead is an expression of the creative power of rhetoric to overcome the linguistic conceptualism and objectification that

\footnotetext{
83 KLEIN, supra note 36, at 66. See Carole Blair, Nietzsche's Lecture Notes on Rhetoric: A Translation, 16 PHIL. \& RHETORIC 94-129 (1983).

${ }^{84}$ HALES \& WELSHON, supra note 37 , at 124.

85 THOMAS, supra note 78 , at 15.

${ }^{86} \mathrm{Id}$. at 2. I would want to add that "Platonism" should be regarded as the received approach, or even Plato's self-understanding, rather than Plato's philosophical activity, which Gadamer has pointed out is rhetorical and dialogic in form. See HANS-GEORG GADAMER ON EDUCATION, POETRY AND History: APPLIED HERMENEUTICS 71 (Dieter Misgeld \& Graeme Nicholson eds., Lawrence Schmidt \& Monica Reuss trans., 1992) ("It is more important to find the words which convince the other than those which can be demonstrated in their truth, once and for all. We can learn this from the Platonic dialogues."). See generally Hans-Georg Gadamer, Dialogue And Dialectic: Eight HeRmeneutical Studies on Plato (P. Christopher Smith trans., 1980).
} 
results from the imperatives of successful communication. Nietzsche praises art for precisely this reason: the artist embodies the rhetorical style that breaks free from tendencies toward absolutism. ${ }^{87}$ Art makes post-theological life bearable because-in addition to serving as a critique of the pretensions of metaphysics, religion, and science-art provides a model of the affirmation of life, a model of the gay science. ${ }^{88}$ Art locates the experience of truth within illusion, and this affirmation of truth captures our nature better than the metaphysical claims of the theologians. ${ }^{89}$

Nietzsche's artist undertakes philosophical questions by embracing rhetorical engagement rather than demonstrative argumentation. Genealogical inquiry is a rhetorical practice because it is an active re-visioning of the significance of the past and the potential for the future rather than an uncovering of timeless verities.

Genealogy's vision is continually directed in three directions at once, always looking toward past, future, and present in a continuing effort to see how each of the three disrupts the others.

It is this continual redirection of forces that constitutes genealogy as critique. It is also a moment of critique that is continually suspended in the field of possibility. In this sense, it is artistic as well, never speaking to the "it was" but only to the "it will have been." The past, for genealogy, always returns from the future retroactively. It is this return, for Nietzsche,

87 Id. at 30; see generally id. at 126-54. Science is theology by other means, but aesthetics celebrates discovery and creation as a unified practice and invites an endless process of innovation that is cumulative without being teleological. Id. at 65-66.

Our ultimate gratitude to art.-If we had not welcomed the arts and invented this kind of cult of the untrue, then the realization of general untruth and mendaciousness that now comes to us through science-the realization that delusion and error are conditions of human knowledge and sensation-would be utterly unbearable. Honesty would lead to nausea and suicide. But now there is a counterforce against our honesty that helps us to avoid such consequences: art as the good will to appearance. We do not always keep our eyes from rounding off something and, as it were, finishing the poem; and then it is no longer eternal imperfection that we carry across the river of becoming - then we have the sense of carrying a goddess, and feel proud and childlike as we perform this service. As an aesthetic phenomenon existence is still bearable for us, and art furnishes us with eyes and hands and above all the good conscience to be able to turn ourselves into such a phenomenon.... We should be able also to stand above morality, . . . but also to float above it and play. How then could we possibly dispense with art-and with the fool?-And as long as you are in any way ashamed before yourselves, you do not yet belong with us.

NiETZSCHE, THE GAY SCIENCE, supra note 33, Book II para. 107, at 163-64. See also id., Book IV para. 299, at 240 ("[W]e want to be the poets of our life-first of all in the smallest, most everyday matters.").

${ }^{89}$ THOMAS, supra note 78 , at 106-07. 
that always effects a stylistic moment. Genealogy is never dispassionate or removed: it is always a mode of "expression, intention, and the art of surprise." 90

Rhetoric is a creative refashioning of accepted topoi to address contemporary questions. It involves a re-visioning, or dynamis, rather than just the skillful application of a methodology to fixed data, as techne. ${ }^{91} \quad$ Nietzsche's genealogy revives the Protagorean formulation, in which man is the measure of all things, and emphasizes man's active and creative role in building a nomos. ${ }^{92}$ At the individual level, Nietzsche characterizes this creative activity as giving style to one's character by working within topoi and constraints that only appear to be limiting. ${ }^{93}$

By embracing the re-visioning power of rhetoric, Nietzsche risks the danger of an untrammeled subjectivism that dissolves into nihilism: "Rhetoric, now capable of making the law, rather than merely representing it, produces, in effect, a new way of seeing, a new epistemology that threatens to undermine nature and reason themselves." ${ }^{4}$ But Nietzsche appeals to the "intellectual conscience" that rises above sophistic relativism. Our ontological fate is to be "relentlessly antidogmatic, antireductionist, antifoundationalist, and ever in search of new interpretations," but Nietzsche emphasizes that "such inquiry results in 'truths' that, though never absolute or ultimate, deliver all that we actually need from truth and, in any case, all we can ever have of it." 95 Translated to a genealogical critique of society, Nietzsche's rhetorical inquiry involves the active adoption of different perspectives and the disruption of received wisdom in order to break free of metaphysical calcifications. Intellectual conscience demands an honest appreciation of the "relationships among perspectives, namely the constant weighing and measuring of interpretations against one another," which in turn serves a number of critical purposes:

First, it demonstrates the partiality of any one interpretation or perspective.... Second, this procedure calls attention to the rules of formation of interpretations and the different sets of these that govern different interpretations, thus highlighting the decisions in favor of one or more of the many criteria that compete for satisfaction in the composition of any

90 Id. at 114 (quoting Friedrich Nietzsche, Genealogy of Morals: A Polemic, in ECCE HOMO (Walter Kaufmann trans., 1967)).

91 Id. at 99.

92 Id. at 54 ("Protagoras's claim amounts to a claim of jurisdiction: the law is now spoken by us, not represented through us.").

93 NIETZSCHE, THE GAY SCIENCE, supra note 33, Book IV para. 290, at 232.

94 THOMAS, supra note 78 , at 55.

95 CoX, supra note 35, at 53. 
interpretation. Thus, entrenchment is weighed against innovation; habit against novelty; simplicity, coherence, utility, and explanatory power against comprehensiveness and precise description, and so on. Third-and highly important for Nietzsche-a consideration of the dominant interpretations of an individual or group produces a whole symptomatology and genealogy of the dispositions and values that motivate these choices... Last, such recognition of the plurality of interpretations and their irreducibility to a single base reveals what Nietzsche calls "the whole marvelous uncertainty and interpretive multiplicity of existence" and thus affirms the world of becoming, change, and semblance. ${ }^{96}$

The promise of intellectual conscience leads Nietzsche to accept the rhetorical construction of the social world with a joyous affirmation.

Nietzschean critique is a rhetorically-structured genealogical inquiry. Because critique is a creative recovery - a re-visioningof the past, Nietzsche rejects a model of critique that is allencompassing or that operates on social structures from the "outside." Rhetoric always connects the critique of pre-given absolutes to the creative affirmation of a (sometimes radically) new formulation of traditional understandings. His genealogical method is highly critical in that it dissembles cultural ossifications, but there is simply nowhere to stand outside of the cultural resources to construct new cultural understandings ex nihilo. Consequently, there is

a kind of double movement in Nietzsche. Generally there is both a yes-saying part and a no-saying part; that is, Nietzsche is almost never purely critical. ...

Even Christianity, which Nietzsche blasts again and again with all the powers at his command, he concedes is not utterly without merit.... Nietzsche destroys previous philosophical structures, only to take their components and re-use them in an original way. ${ }^{97}$

96 Id. at 55-56 (quoting The Gay Science para. 2).

${ }^{97}$ HAles \& WElshon, supra note 37, at 8-9. This doesn't suggest that Nietzsche's critiques are superficial, but instead uncovers the extent of his radical remaking of the tradition. In his diatribe against Christianity, Nietzsche makes clear that he doesn't seek to obliterate Christianity but instead to recover its significance and subsequent decadence: "I go back, I tell the genuine history of Christianity." NiETzSCHE, The Antichrist, supra note 40 , para. 39, at 612. Nietzsche's radical remaking of tradition is perhaps most evident in the development of his perspectivist ontology:

Now, having ripped apart the edifice of metaphysics, he pokes among the ruins to see what, if anything, can be salvaged. Yet, unlike Descartes, who also though he had demolished a house of belief only to construct a new one suspiciously similar to the old, Nietzsche does something more radical: from the scraps of the absolutist metaphysical tradition, he begins to piece together an ontology that is explicitly and thoroughly perspectivist. 
This is the rhetorician's wisdom and skill: refashioning the bonds of social cohesion in new ways to meet the demands of the present. Nietzsche makes clear that an unceasing and uncompromising critique would undermine the gay science that he heralds. ${ }^{98}$ Critique is always a destructive construction, just as a rhetorical refashioning of accepted premises undermines the absolutism of these premises.

Nietzschean critique is a rhetorical activity that acknowledges its rhetoricity. Nietzsche challenges the cultural understandings of his day through genealogical criticism that simultaneously loosens the encrustation of habitual thinking and refashions a dramatically new understanding of cultural traditions. He employs a naturalistic critique because he appeals to the emerging interpretations that define social reality, even if they remain repressed and are denied. His famous announcement of the death of God is not a suggestion for change made by an all-knowing critic; rather, it is a commentary on what already has occurred, a rhetorical assessment of shifts that are underway but remain unacknowledged. Nietzsche's critical activity is consistent with his perspectivist ontology, because rather than proposing an eternally valid description of the human condition he offers an interpretation of a shared reality that is subject to criticism and refinement. Nietzsche confronts the human condition with joy and openness rather than hiding behind the fables that no longer ring true (Christianity) or the new fables that similarly obscure the human condition (positivist natural science).

\footnotetext{
Hales \& Welshon, supra note 37, at 62. See NieTzSCHE, What is Noble, supra note 42, para. 280 , at 224 :

"Too bad! What? Isn't he going-back?"

Yes, but you understand him badly when you complain. He is going back like Id.

98 NiETZSCHE, The GAy SCIENCE, supra note 33, Book II para. 76, at 130. Nietzsche claims to "love brief habits" that yield much knowledge, but to "hate" the "tyrant" of enduring habits. And yet, he makes clear that an unceasing critique of all habits, the effort to extricate oneself from a rhetorically-secured social context altogether, would be unbearable.

Most intolerable, to be sure, and the terrible par excellence would be for me a life entirely devoid of habits, a life that would demand perpetual improvisation. That would be my exile and my Siberia. Id. Book IV para. 295, at 237.
} 


\section{THE HERMENEUTICAL CHARACTER OF NIETZSCHEAN CRITIQUE AND THE CRITICAL DIMENSION OF PHILOSOPHICAL HERMENEUTICS}

Rather than a centripetal activity issuing from the subjectcentered rationality of an isolated epistemological, moral, or aesthetic subject, we understand critique as a centrifugal deployment of discursive and nondiscursive social practices....

Critique, refigured as praxial critique, enjoys neither modernity's zeal for foundations nor its hopes for the attainment of certainty. It rests content to discern and assess the play of forms of thought and action against the background of changing and historically conditioned patterns of signification.

-Calvin O. Schrag ${ }^{99}$

My model of Nietzschean critique captures Nietzsche's vibrant critical spirit without surrendering the rhetorical rationality at work in his writings. Having rescued Nietzsche from the polar excesses of his postmodern readers and his neo-Kantian analytic readers, my model of Nietzschean critique offers a provocation for rethinking the possibility of critical theory within Gadamer's philosophical hermeneutics. Nietzsche's radical-often shrillirreverence admittedly stands in sharp contrast to Gadamer's veneration of the resources of tradition that continually are remade in hermeneutical exchanges. The prejudiced reception of each philosopher-construing Gadamer as a conservative traditionalist and Nietzsche as a postmodern nihilist-has precluded an investigation into the potential connections between their work. Nevertheless, Nietzschean critique shares substantial features with Gadamerian hermeneutics. I do not intend to unify their philosophies with flattening and facile readings of their work, or to subjugate Nietzsche to Gadamer. Instead, my goal is to draw connections that permit each philosopher to engage the other. Working from my model of Nietzschean critique, there is ample room for a productive and edifying dialogue.

There is no real precedent for reading Nietzsche and Gadamer together. ${ }^{100}$ Although Gadamer writes extensively about

99 Calvin O. Schrag, The Resources of Rationality: A Response to THE POSTMODERN CHALLENGE 57 (1992).

${ }^{100}$ I have only found one example in the commentary written in English. In a recent article Craig Allen Beam suggests that "if hermeneutics is ever to put to rest the accusation that it is too conservative and not sufficiently critical, Nietzsche is helpful both as an ally and a supplement to Gadamer," while also noting that as yet there has been no 
the philosophical tradition generally, and the important resources within German philosophy particularly, he is surprisingly silent about the relevance of Nietzsche's philosophy to his work. ${ }^{101}$

effort to draw these connections. Craig Allen Beam, Gadamer and MacIntyre: Tradition as a Resource of Rationality, 25 KINESIS 15, 28, $31 \mathrm{n} .14$ (1998). I offer this article as a detailed elaboration of how these connections might be drawn, consistent with Beam's very brief overview.

101 One possible interpretation of Gadamer's silence is to suppose that he considered Nietzsche to be more of a literary figure than a philosopher. In an essay devoted to Nietzsche's work, Gadamer offers a reading of Zarathustra that might appear to suggest that Gadamer believes Nietzsche to be more a "stylist" and a "poet" than a true philosopher. See generally Hans-Georg Gadamer, The Drama of Zarathustra, in NiETZSCHE's New SEAS: EXPLORATIONS IN Philosophy, AesTHeTICS AND POLITICS 220 (Michael Allen Gillespie \& Tracy B. Strong eds., Thomas Heilke trans., 1988). However, Gadamer acknowledges that Zarathustra's dialogues are not merely cover for didactic monologues, nor are they purely aesthetic. Gadamer takes Zarathustra's semipoetic dialogues seriously because they resolutely resist being absorbed into Nietzsche's mature doctrines, doctrines that Heidegger famously characterized as representing the culmination of metaphysical thinking. In Zarathustra's dialogues, Gadamer discovers, the voice of the philosopher speaks without reaffirming the grip of western metaphysics:

In the end, the inheritance of metaphysics is preserved in Nietzsche's radical critique of consciousness and self-consciousness from the perspective of life, and in his sketch of a universal theory of the will to power, and this metaphysics, as Heidegger has correctly seen, terminates in the mastery of all being, in the rule of technology. In contrast, the drama of Zarathustra imparts another teaching. The teacher and cultivator, the revaluator of all values, who wants to be Zarathustra, must in the end say to his soul, "Sing, speak no more!"

What does this aim at? Certainly to show that no doctrine that sees the will to power at work in everything and that tears the mask from truth, one after the other, can ever reach an end .... .

Id. at 230-31. In short, Gadamer finds in Nietzsche's dialogues, much as he finds in Plato's dialogues, confirmation of his hermeneutical-rhetorical orientation.

This short essay aside, Gadamer's only sustained attention (in translation) to Nietzsche's philosophical importance occurred during his famous "non-conversation" with Jacques Derrida at the Goethe Institute in Paris during 1981. Gadamer prepared a lengthy paper for the meeting, tracing the divergence of French deconstruction and German hermeneutics to competing interpretations of Heidegger, and he characterized the deconstructive reading of Heidegger as one that incorrectly championed radical readings of Nietzsche's thought. Gadamer observes that Derrida and his followers "have not grasped the significance of the seductive in Nietzsche's thought," which leads them to embrace the same extreme "self-dissolution" of metaphysics. Hans-Georg Gadamer, Text and Interpretation, in DiAlogue AND DECONSTRUCTION: THE GADAMER-DERRIDA EnCOUnTER 25 (Diane P. Michelfelder \& Richard E. Palmer eds., Dennis J. Schmidt \& Richard Palmer trans., 1989) (1984). In response to Derrida's cryptic and largely nonresponsive reply to his paper, Gadamer expresses his frustration by comparing Derrida's style to Nietzsche's style.

Is [Derrida] really disappointed that we cannot understand each other? Indeed not, for in his view this would be a relapse into metaphysics. He will, in fact, be pleased, because he takes this private experience of disillusionment to confirm his own metaphysics. But I cannot see here how he can be right only with respect to himself, be in agreement only with himself. Of course I understand very well why he invokes Nietzsche here. It is precisely because both of them are mistaken about themselves. Actually both speak and write in order to be understood.

Hans-Georg Gadamer, Reply to Jacques Derrida, in Dialogue And DeConstruction: 
THE GADAMER-DERRIDA EnCOUNTER 55, $56-57$ (Diane P. Michelfelder \& Richard E. Palmer eds., Dennis J. Schmidt \& Richard Palmer trans., 1989) (1984). Gadamer's rejection of Nietzsche would appear to be unequivocal, but in the course of his formal paper he acknowledges Nietzsche's role in subverting positivism and logocentrism, and appears to demonstrate a more balanced appreciation of Nietzsche's importance. This would accord with Gadamer's essay on Zarathustra's dialogic significance. It is likely, then, that it is the reading of Nietzsche by Derrida and the French deconstructionists that provides Gadamer's foil, rather than Nietzsche himself. Later, in a letter to Fred Dallmayr regarding his encounter with Derrida, Gadamer acknowledged that it is precisely the "fundamentally different ways" in which Nietzsche can be read that divided him from Derrida; he also aligned himself with Heidegger's reading of Nietzsche as the "self-disintegration of metaphysics" that leads to a search for a "bridge into a new language, into another thinking (which perhaps does not even exist)." Hans-Georg Gadamer, Letter to Dallmayr, in Dialogue And DeCONSTRuCtion: THE GADAMERDERRIDA ENCOUNTER 93, 93-94 (Diane P. Michelfelder \& Richard E. Palmer eds., Dennis J. Schmidt \& Richard Palmer trans., 1989). As suggested in the quote above, Gadamer appears to believe only that Nietzsche's commentators, and perhaps Nietzsche himself, have misinterpreted Nietzsche's philosophical initiatives, which is different from rejecting those initiatives. Given the context of this meeting with Derrida, I do not regard Gadamer's comments as precluding my reading of his philosophy in concert with Nietzsche's philosophy.

Still, it remains curious (to say the least) that Gadamer did not engage Nietzsche's thought during his long career, and recent autobiographical information suggests that Gadamer expressly chose to avoid such an encounter because he believed that it would not be a productive avenue for his thought. Gadamer regards himself as a student of Heidegger, but he does not follow Heidegger's thought as much as he challenges Heidegger's thought from within. It may very well be that a principal point of distinction between his work and Heidegger's is Gadamer's belief that Heidegger's confrontation with Nietzsche was ill-fated.

Gadamer suggests... that Heidegger in part, [with respect to his interpretation of the pre-Socratics] as elsewhere, was misled by his reliance on Nietzsche.

....

In a recent interview, Gadamer reports that shortly before his death Heidegger told his family that Nietzsche had ruined him. Whereas Heidegger had largely oriented his hermeneutical effort around a confrontation with Nietzsche, Gadamer acknowledges that his hermeneutical orientation, whose impulse came in the first place from Heidegger, is a critical response to Dilthey.

... Unlike Heidegger... Gadamer does not paint a dark and apocalyptic picture of our age. He finds Heidegger's dismal view as overdramatized, dangerous, and hubristic. Gadamer writes, for example: “Don't we all run the risk of a terrible intellectual hubris if we equate Nietzsche's anticipations and the ideological confusion of the present with life as it is actually lived with its own forms of solidarity? Here, in fact, my divergence from Heidegger is fundamental."

Robert J. Dostal, Gadamer's Relation to Heidegger and Phenomenology, in THE CAMBRIDGe COMPANION TO GADAMER 260-62 (Robert J. Dostal ed., 2002) (quoting Hans-Georg Gadamer, A Letter by Professor Hans-Georg Gadamer, in RICHARD BERNSTEIN, BEYOND OBJECTIVISM AND RELATIVISM 261, 264 (1983)). Again, I believe that Gadamer's motivations and assumptions for avoiding Nietzsche (shaped, undoubtedly, by Heidegger's disastrous and embarrassing relationship with the Nazi Party during the war as much as purely scholarly reasons) do not undermine my claim that a Gadamerian reading of Nietzsche could have overcome the errors in Heidegger's approach that Gadamer diagnosed.

Even if the evidence led me to conclude that Gadamer rejected the claim that there could be any profitable connections between his work and Nietzsche's philosophy, I would regard his position as mistaken and argue that this article demonstrates that Gadamer was 
However, in a revealing passage in his intellectual autobiography, Gadamer suggests that one of the driving forces behind his work was the desire to find a means of engaging in philosophical thinking in the wake of Nietzsche's undeniable legacy. ${ }^{102}$ Gadamer generally has succeeded, in my judgment, but his work can benefit tremendously from a more explicit and direct engagement with Nietzschean critique.

Without claiming to be exhaustive, I will discuss three important points of convergence between philosophical hermeneutics and Nietzschean critique. First, Nietzsche's perspectivist epistemology bears important similarities to Gadamer's contention that understanding involves a fusion of horizons. Additionally, both philosophers place importance on the rhetorical tradition and the possibility of rhetorical knowledge. Finally, in what may be a surprising and little noticed way, Nietzsche's unremitting challenge to traditional understandings exemplifies Gadamer's emphasis on the importance of tradition to understanding. Using these three topics as a focus, my goal is to position Nietzschean critique and Gadamerian philosophical hermeneutics as provocative and challenging supplements to each other. I can't think of a more appropriate way to celebrate the perspectival character of knowledge and the inevitability of the fusion of horizons than this effort to read Nietzsche and Gadamer together.

\section{A. Perspectivism and Fusion of Horizons}

Nietzschean critique is grounded in an ontology, but it is a thoroughly perspectivist ontology. Ontological perspectivism promotes openness to multiple perspectives as a response to the perspectival character of truth, and not simply as a methodology

\footnotetext{
wrong about his own philosophical initiatives. However, I do not believe that the evidence requires me to make such a presumptuous claim.

102 Gadamer writes that in his formative years he found in Martin Heidegger "a thinker whose philosophical power was adequate to the powerful initiatives put forward by Nietzsche ... [answering] the gigantic form of Friedrich Nietzsche with his ecstatic critique of everything, including the illusions of self-consciousness." Hans-Georg Gadamer, Reflections on My Philosophical Journey, in THE PHILOSOPHY OF HANS-GEORG GADAMER 3, 6-7 (Lewis Edwin Hahn ed., Richard E. Palmer trans., 1997). In his further reflections on his ill-fated encounter with Derrida in 1981, see supra note 101, Gadamer suggests that the very challenge of his hermeneutics is "to take up Nietzsche in a thoughtful way," which would mean to recognize that someone who takes "deconstruction to heart and insists on difference stands at the beginning of a conversation, not at its end." Hans-Georg Gadamer, Destruktion and Deconstruction, in DIALOGUE AND DECONSTRUCTION: THE GADAMER-DERRIDA ENCOUNTER 102, 113 (Diane P. Michelfelder \& Richard E. Palmer eds., Geoff Waite \& Richard Palmer trans., 1989) (1985).
} 
for gaining better access to bedrock, unitary truth. Nietzsche's ontological perspectivism immediately lends itself to comparisons to Gadamer's famous claim that a "fusion of horizons" marks every interpretive event. ${ }^{103}$ Just as Nietzsche argues that the perspectival nature of reality requires us to embrace many different perspectives in pursuit of truth, Gadamer argues that the hermeneutical nature of reality requires a fusion of horizons if we are to understand a traditionary text. Gadamer's ontological account of human understanding therefore shares the same curious structure as Nietzsche's ontological account: both philosophers deny that there can be perspective-independent truths that remain insulated from the activity of knowing.

Despite this initial similarity, there clearly are important differences between the two concepts. Nietzsche's perspectivism leads him to be wary of his interlocutors. If other thinkers can only have a partial perspective, then it follows that the critic must constantly be on guard against being co-opted by the limited views of those with whom he interacts. Wariness is particularly appropriate in light of Nietzsche's constant emphasis that only a few bold thinkers have been able to overcome the suffocating perspective of "herd mentality" by moving beyond the patently absurd religious and metaphysical myths that defined European culture in his day. Nietzsche concedes that the critic is no less bound by his perspective, but he contends that the critic can broaden his perspective by opening himself to will to power, the unconscious play of perspectival forces that lies behind the conscious myth-making of most philosophizing.

In contrast, Gadamer places great emphasis on learning from others by engaging them in a hermeneutical event of understanding in which one accepts the potential superiority of the other's perspective. Understanding is not a question of determining whose perspective is superior, Gadamer argues, but rather in discovering that each person's previous understandings are limited, and that new understanding results from moving beyond the two prejudiced perspectives by fashioning a new (yet still perspectival) understanding. Gadamer enjoins critical theorists to abandon their wariness and sense of superiority, and he emphatically rejects monological models of critique. Critical insight is gained by engaging others in an educative experience of understanding.

If Nietzsche is too wary of the necessarily limited perspectives

103 This connection is briefly suggested by Beam: "Thus, far from being a postmodern nihilist, Nietzsche challenges us to broaden and enrich our point of view through something like the hermeneutic fusion of horizons." Beam, supra note 100, at 27. 
of his interlocutors, Gadamer is too wary of his own limited perspective in deferring to his dialogue partners. Although this is not merely a difference in accents or a conflict among subsidiary themes, it would be a mistake to conclude that Nietzsche and Gadamer are fundamentally incompatible. The initially plausible connection between perspectivism and the fusion of horizons must be tempered by a realistic account of their different approaches, but I believe that acknowledging these differences leads to a better understanding of the issues that both thinkers raise.

Nietzsche clearly is ambivalent about the prospects for a productive fusion of horizons with a dialogue partner. On one hand, Nietzsche agrees that a critic must continually move beyond his own limited perspective. Against the moralists obsessed with self-control and self-sufficiency, he argues that one "must be able to lose one-self occasionally if one wants to learn something from things different from oneself." 104 Nietzsche argues that this process of renewal is not subject to rational and methodological direction, but rather is a product of critically engaging previously held truths. ${ }^{105} \mathrm{He}$ notes that it is a matter of good luck if one is fated to have believed for a time in the cause of one's contemporary opponents, since it is this direct experience of perspectivity that can liberate the critic from narrow-mindedness. ${ }^{106}$ On the other hand, Nietzsche remains skeptical that his contemporaries can offer him much insight from their limited perspectives. Nietzsche mocks the false humility of accepting criticisms of one's own limitations, contending that the critic's counterattacks on hallowed cultural truths are a much more significant event. ${ }^{107}$ Nietzsche's critic is a wanderer who escapes the confining morality of his own culture in order to gain perspective on its perspectivity. ${ }^{108}$ This theme comes through most starkly in Nietzsche's frequent references, particularly in Beyond Good and Evil, to the herd mentality that the critic must strive to avoid in the exercise of intellectual conscience.

The wariness of others' limitations is perhaps best captured in Nietzsche's counsel to avoid engaging others with the goal of changing them, and instead to pursue the higher goal of generalized cultural critique.

New caution.-Let us stop thinking so much about

104 NiETZSCHE, THE GAY SCIENCE, supra note 33, Book IV para. 305, at 245.

105 Id. Book IV para. 307, at 245.

106 Id. Book IV para. 323, at 255 ("Good luck in fate. - The greatest distinction that fate can bestow on us is to let us fight for a time on the side of our opponents. With that we are predestined for a great victory.").

107 Id. Book IV para. 297, at 239.

108 Id. Book V para. 380, at 342. 
punishing, reproaching, and improving others! We rarely change an individual, and if we should succeed for once, something may also have been accomplished, unnoticed: we may have been changed by him. Let us rather see to it that our own influence on all that is yet to come balances and outweighs his influence. Let us not contend in a direct fight-and that is what all reproaching, punishing, and attempts to improve others amount to. Let us rather raise ourselves that much higher. Let us color our own example ever more brilliantly. Let our brilliance make them look dark. No, let us not become darker ourselves on their account, like all those who punish others and feel dissatisfied. Let us sooner step aside. Let us look away. ${ }^{109}$

At first glance, Nietzsche appears to be discounting the possibility of productive exchanges with others by noting the threat of being co-opted by the herd mentality. But this passage is better understood as a plea for critics to stop engaging others from a position of presumed superiority, since this posture only reinforces the limited perspective of the critic and thus reinscribes the prevailing morality. Nietzsche continually emphasizes the positive nature of critique, which is the hallmark of his gay science. ${ }^{110} \mathrm{He}$ desperately wants to move beyond a moralistic reproach that is grounded in a fixed and unyielding perspective by foregoing the urge to chastise others; instead, he wants to critique morality itself. It is not the fruitlessness of the fusion of horizons that worries Nietzsche, then, but rather the inevitable tendency to be drawn into the temptation to subjugate others to our own horizons, thereby reinforcing rather than challenging one's perspective from within a prevailing morality.

Nietzsche remains silent about how the critic is supposed to rise above his cultural limitations to become a wanderer. There is ample evidence in his texts and in his own life that Nietzsche may have regarded this task as a monological endeavor that avoids the inevitable pitfalls of engaged dialogue within prevailing social strictures. But it should be apparent that this position would undercut much of Nietzsche's radicalism, and would contradict the undeniably rhetorical character of his writings. Even if Nietzsche viewed himself as being competent to proceed monologically, Nietzschean critique is best realized by rejecting monologism. I contend that Gadamer's concept of the fusion of horizons provides the best account of how the Nietzschean critic can move beyond his own prejudiced perspective, rejecting the presumptuous sovereignty of univocal criticism while also eschewing a crude

\footnotetext{
109 Id. Book IV para. 321, at 254.

${ }^{110}$ Id. Book IV para. 276, at 223; id. para. 304, at 244.
} 
moralistic critique of the other that reaffirms prevailing structures of thought. Gadamer's corrective, though, must also be reassessed in light of Nietzsche's insights.

Gadamer uses the concept of the fusion of horizons in Truth and Method to describe the historicality of the experience of understanding. He emphasizes that there are no distinct horizons to be fused, since the horizon of the present always imports within it the horizon of the past. Gadamer discusses a "fusion" only to highlight the dynamic tension between present understanding and the past, leading to his conclusion that "understanding is always the fusion of these horizons supposedly existing by themselves." Crude historicism posits the past as something that is inert and accessible to us as an object, but the activity of positing the past always is an application of the past to the present in the form of an interpretation, and so this activity reveals the living power of the supposedly closed horizon of the past. ${ }^{112}$ The interpenetration of past and present means that the reverse also holds true: the past horizon is always re-created in the course of being posited by the present horizon. ${ }^{113}$ Applied to textual interpretation, Gadamer argues that the fusion of horizons means that a traditionary text can have no meaning in itself, because it has meaning only in relation to the questioning that it provokes in a situated reader. ${ }^{114}$ In short, Gadamer's principal theme is that understanding is historically conditioned.

Gadamer extends his discussion of fusion of horizons to the experience of dialogue with another, and certainly he would endorse a respectful and charitable engagement with another person rather than a dismissive refusal to accept the potential superiority of the other's understanding. But this ethical and pragmatic implication of his philosophy should not be mistaken for his philosophical point. At any given moment there are numerous individuals who are unlikely to bring something productive to a conversation with the critic because they are wholly given over to reigning ideologies. However, understanding is always a product of a dialogue that operates as an application of the past to the present, even if a particular individual does not facilitate this process. Gadamer writes about the provocations that we find in the supposedly closed horizon in the past, but in a revealing

\footnotetext{
111 GADAMER, supra note 1, at 306.

112 Id. at 307.

113 Id. at 374 .

114 Id. at 397 ("The historical life of a tradition depends on being constantly assimilated and interpreted. An interpretation that was correct in itself would be a foolish ideal that mistook the nature of tradition. Every interpretation has to adapt itself to the hermeneutical situation to which it belongs.").
} 
footnote added to the fifth German edition of Truth and Method, Gadamer suggests that it is not only temporal distance that opens the space for critique. Elsewhere I have argued that Gadamer's later attention to multiculturalism provides one example of "dialogic distance" that is not temporal in nature. ${ }^{115}$ His doctrine of fusion of horizons is not a claim that we must accept everyone's opinion to some degree, but rather is that other horizonswhether provided by the past, distinct cultures, or other distanced perspectives-can provoke us to overcome our own limitations. Nietzsche bemoans the limitations of German culture for this very reason: his contemporaries were locked in a horizon that stultified thinking rather than provoking new understandings.

It is now clear that the difference between Nietzsche's perspectivism and Gadamer's fusion of horizons is that Nietzsche is primarily concerned with the stultifying effects of horizontal relationships within a cultural horizon, whereas Gadamer is primarily concerned with promoting the educative effects of vertical relationships through time. The similarity between their accounts is explained by the fact that these two features are closely related, whereas the differences in their accounts are best explained by the important distinctions between these two experiences. Nietzsche's perspectivism naturally leads him to mistrust the contemporary understanding of the "herd animals," which often pose as universal and eternal truths. But it is Gadamer's concept of the fusion of horizons that is most effective in destabilizing these false claims and re-situating understanding in an ongoing dynamic application of the past to present circumstances. Nietzsche's perspectivism cautions us against looking for quick answers from our cultural contemporaries, whereas Gadamer's analysis of fusion of horizons encourages us to exploit the continuing and creative application of previous understandings in a new setting as the manner in which parochialism is exposed and (incompletely) overcome. Read together, Nietzsche and Gadamer reveal that it is foolish and counterproductive for a cultural critic to claim to have all the answers and to disparage the prejudiced perspectives of his contemporaries, but also that it is equally foolish for the critic to disable his critical agency in the face of his own prejudiced forestructure of understanding as a participant within a cultural

115 See Francis J. Mootz III, Legal Classics: After Deconstructing the Legal Canon, 72 N.C. L. REV. 977, 1023 (1994). Fred Dallmayr has elaborated this Gadamerian theme in his recent books, with his customary grace and erudition. See Fred R. DALlMayr, ALTERNATIVE VISIONS (1998); FRED DALLMAYR, BEYOND ORIENTALISM: ESSAYS ON CROSS-CUlTURAL ENCOUNTER (1996). 
perspective.

\section{B. Philosophy and the Rhetorical Tradition}

Analyzing the connections between perspectivism and fusion of horizons only introduces the extent to which Nietzsche and Gadamer can profitably be read together. This initial point of convergence is enriched by comparing how Gadamer and Nietzsche emphasize the rhetorical nature of critical theory, because it is in rhetorical engagement that perspectives are revealed and the dynamic of fusion of horizons occur. Nietzsche provides more explicit guidance than Gadamer, both in his thematic development and by the degree to which he exemplifies the rhetorical character of philosophical thinking. Nevertheless, Gadamer is not so far removed from Nietzsche in this regard as one might assume. Closer examination reveals that Nietzschean critique can be compared profitably with Gadamer's rhetorical model of understanding, even though Gadamer appears to acknowledge that rhetoric is only a minor theme of his work.

Nietzsche's philosophical activity is expressly rhetorical in both theme and format. He embodies the "dangerous maybe" in his work by challenging prevailing conceptions and prevailing philosophical conventions. His genealogical inquiry recuperates the significance of the past with artful interpretations that appeal only to "intellectual conscience" rather than eternal truths. By seeking to loosen the grip of encrusted thought, which is to say the solidification of past rhetorical engagements into dogma, Nietzsche assumes the role of the ancient rhetoricians in seeking adherence to claims that are subject to persuasion but not demonstration. This aspect of Nietzsche's thinking is manifest and widely acknowledged.

The rhetorical dimension of Gadamer's philosophy is much less overt. His masterwork, Truth and Method, lumbers through 500 pages of relatively conventional philosophical discourse, in which he scarcely mentions the rhetorical tradition. Nevertheless, Gadamer's extended analysis of conversation as the paradigm of hermeneutical understanding certainly suggests that the rhetorical tradition is critical to his work, and this is confirmed by his brief (but prominent) discussion in Truth and Method of the need to recuperate Vico's development of the concept of sensus communis. Gadamer aligns Vico with the substantive rhetorical goal of saying the right thing well, and applauds his development of the "positive 
ambiguity of the rhetorical ideal."116 At the end of the book, Gadamer reminds the reader that a central feature of his argument has been the recovery and rehabilitation of the rhetorical model of knowledge, even though this theme has virtually disappeared from explicit discussion in the ensuing pages. ${ }^{117}$ Picking up on these explicit, but often overlooked, references, Klaus Dockhorn's review of Truth and Method argued that Gadamer underestimated the extent to which the rhetorical tradition underwrites his project, but he nevertheless predicted that the "widespread depreciation or dismissal of rhetoric ... should be effectively brought to an end by" Truth and Method. ${ }^{118}$

In subsequent essays, Gadamer more clearly indicated that his hermeneutical philosophy was aligned with rhetorical insights. ${ }^{119}$ In particular, Gadamer invoked the rhetorical tradition in response to the charge by Habermas and others that his hermeneutical philosophy was overly protective of the status quo. In his 1972 "Afterword" to the third German edition of Truth and Method, Gadamer responded by characterizing Habermas's rejection of rhetoric in favor of the ideal speech situation of rational discourse as "frighteningly unreal."120 Gadamer argues that the ancient rhetorical tradition concerned the art of persuasion when there are multiple reasonable views that cannot be rationally resolved:

I would like to see more recognition of the fact that this is the realm hermeneutics shares with rhetoric: the realm of arguments that are convincing (which is not the same as logically compelling). It is the realm of practice and humanity in general, and its province is not where the power of "iron-clad conclusions" must be accepted without discussion, nor where emancipatory reflection is certain of its "contrafactual agreements," but rather where controversial issues are decided by reasonable consideration. ${ }^{121}$

Gadamer expressly recognizes the importance of rhetoric to his hermeneutical philosophy, and in his later essays he agrees that it is rhetorical exchanges that open the hermeneutical situation to

116 GADAMER, supra note 1 , at 20.

117 Id. at 485 .

118 Klaus Dockhorn, Hans-Georg Gadamer's Truth and Method, 13 PHIL. \& RHETORIC 160,160 (1980).

119 See, e.g., Hans-Georg Gadamer, The Relevance of the Beautiful, in THE RELEVANCE OF THE BEAUTIFUl AND OTHER ESSAYS 17 (Robert Bernasconi ed., Nicholas Walker trans., 1986) (1977); Hans-Georg Gadamer, Hermeneutics as a Theoretical and Practical Task, in REASON IN THE AGE OF SCIENCE 113-38 (Frederick G. Lawrence trans., 1981) (1978); Hans-Georg Gadamer, The Expressive Power of Language, 107 PUBLICATIONS MOD. LANGUAGE ASS'N AN. 348-52 (1992).

120 GADAMER, supra note 1 , at 568.

${ }^{121}$ Id. 
critical insight. ${ }^{122}$

In addition to these thematic developments in Gadamer's more recent work, on closer examination it is clear that Gadamer's philosophical activity exemplifies the rhetorical dimension of his thought. Truth and Method is a rather ungainly book despite its justly earned renown, but Gadamer has not defined his philosophical career with the production of scholarly books. Instead, the bulk of his "writings" are essays and transcripts of speeches that he has given throughout his long career. In the translator's introduction to a recent collection of essays, Chris Dawson notes that "Gadamer reads like a great rhetorician, which is what he really is. His rehabilitation of rhetoric is the principal original element in his philosophy, and he uses rhetoric as much as he advocates it."123 Much like Nietzsche, then, Gadamer is a cultural critic who writes and speaks in order to persuade his audience about matters that are not subject to a compelling proof:

If we are looking for specific claims supported by watertight arguments, then, we shall find Gadamer irritating and shallow. But if we are looking for ways of approaching really deep questions about the world and our place in it, or if we are looking for some kind of orientation in modern society and are frustrated by the lack of any external viewpoint from which to examine it, we shall find Gadamer's historical rhetoric thrilling and invigorating.

122 Gadamer's other extended discussion of rhetoric similarly occurs in the context of defending his approach from the challenges issued by Habermas. See HANS-GEORG GADAMER, On the Scope and Function of Hermeneutical Reflection, in PHILOSOPHICAL HeRMENEuTICs (David E. Linge ed., 1976) (G.B. Hess \& R.E. Palmer trans., 1967) (demonstrating that the scientistic claims of critical sociology fail for the same reason that scientistic approaches to rhetoric and hermeneutics fail to capture the full scope of the experiences of persuasion and understanding). It is not happenstance that Gadamer invokes rhetoric extensively in the latter essay, since he is not only rebutting Habermas's critical theory but also absorbing and responding to Klaus Dockhorn's review of Truth and Method. Dockhorn argues that, despite scant references to rhetoric, the entire argument of Truth and Method is suffused with the concepts of the rhetorical tradition, see Dockhorn, supra note 118 , at 161 , and Gadamer readily accepts this characterization as a helpful clarification of his thesis, see GADAMER, supra, at $43 \mathrm{nn} .3,6 \& 7$.

In his most recent commentary on his philosophy, Gadamer has chosen to highlight the rhetorical themes that guided his thinking and therefore bring to the forefront what earlier was only intimated by his discussion of Vico. See Hans-Georg Gadamer, Reflections on My Philosophical Journey, in ThE Philosophy of Hans-GeorG GADAMER 30 (Lewis Edwin Hahn ed., Richard E. Palmer trans., 1997); Hans-Georg Gadamer, Reply to Donald Phillip Verene, in The Philosophy of Hans-GeorG GADAMER, supra, at 154 (commending Verene's "more precise elaboration" of the elements of Vico's philosophy that are relevant to Gadamer's project); HANS-GEORG GADAMER, The Expressive Force of Language: On the Function of Rhetoric in Gaining Knowledge, in PRAISE OF THEORY 123-34 (Chris Dawson trans., 1998) (1979) (noting that rhetoric remains central despite the ascendency of the model of the natural sciences).

12.3 Chris Dawson, Translator's Introduction to PRAISE OF THEORY, supra note 122, at xv-xxxviii, xvi. 
.

We must not be deceived by Gadamer's chatty style, which ... conceals a wealth of subtle thinking and artistry. Gadamer deals with real and serious problems, and goes only as far with them as he is sure he is justified in doing. . . . [His approach is to use] rhetoric to build a communal solidarity in which we can find balances and compromises that will allow us to make better sense of ourselves and the world we share. ${ }^{124}$

As Gadamer aptly put the point in response to an interviewer's question about the alleged lack of philosophical precision in his writings, "It may be a cultivated thing to eat with a knife and fork, but that is not the right approach in philosophy." 25 Gadamer eschews the role of the know-it-all professional philosopher who can first determine and then pronounce the truth from a removed distance. Instead, he seeks rhetorical engagement with his readers. Looking beyond the monumental Truth and Method, then, Gadamer's philosophy of rhetoric converges with his rhetorical style to reveal an engaged thinker, teacher and citizen.

A careful consideration of their work shows that Gadamer and Nietzsche are aligned in their recuperation of classical rhetoric as an antidote to the lifeless, technocratic consciousness of modernity. Despite this juncture in their thinking, it remains necessary, as with my comparison of perspectivism and fusion of horizons, to resist the temptation to offer a facile reading that collapses their distinct approaches into a unified account. Gadamer's attention to rhetorical engagement can profitably be compared with Nietzsche's rhetorical style, but it is essential to understand that the two thinkers are not covering the same ground.

Nietzsche employs rhetoric in the sense that he searches for appropriate tools of persuasion; he makes claims on an audience with the goal of persuading them rather than approaching them with an openness to reaching mutual understanding. ${ }^{126}$ Although Gadamer's numerous essays and addresses display subtle social

124 Id. at xviii-xix, xxxvii-xxxviii.

125 Hans-Georg Gadamer on Education, Poetry and History: Applied HeRmeneutics 7 (Dieter Misgeld \& Graeme Nicholson eds., Lawrence Schmidt \& Monica Reuss trans., 1992).

${ }^{126}$ Here, we should recall Aristotle's definition of rhetoric as "an ability in each [particular] case, to see the available means of persuasion." ARISTOTLE, ON RHETORIC 36 (George A. Kennedy trans., 1991) (circa 350 A.D.). In other words, rhetoric is the artistic skill of being able to find the best means of persuading a particular audience, rather than the result of successfully persuading them or the perception of a truth that is independent of one's ability to persuade others. Nietzsche works to find the means of persuasion: given the weaknesses of his audience he does not make successful persuasion his primary concern, but neither does he retreat into solipsism. 
critique, his philosophical focus is an investigation of the hermeneutical dimension that subtends such partisan argumentation oriented to persuading an audience. It is perhaps most accurate to describe his project as uncovering the dynamic intersubjective reality that subtends rhetorical exchanges even as he advances his own cultural criticisms. These important differences in focus clarify the similar use of the rhetorical tradition by both thinkers. Read together, Nietzsche's rhetoric and Gadamer's rhetorical engagement provide much need assistance in the effort to develop a critical hermeneutics.

Given Gadamer's rather limited discussion of the rhetorical tradition, Nietzsche is best deployed as a means of "completing" Gadamer's rhetorical line of inquiry. Gadamer makes a vital contribution to the postmodern destruction of the metaphysics of presence by recuperating the rhetorical tradition's lesson that reasonable inquiry is grounded in the hermeneutical situation of limited horizons reaching understanding in a "fusion." Gadamer consistently uses this rhetorical lesson to undermine subjectivity by replacing demonstration with an intersubjective coming-toagreement. Nietzsche works from a similar ontological account, but Nietzsche exemplifies the conversation partner who works to break "free" of ordinary conversational constraints by subjecting the conversation itself to rhetorical reassessment and invention. Nietzsche brings the hermeneutics of suspicion to bear on the rhetorical situation: because he is wary of his audience, he is unwilling to accept the ordinary inventiveness that occurs in the use of rhetorical commonplaces with which the audience constitutes itself. He does not escape the commonplaces, of course, but he strives to rework them in dramatic ways that reveal their character as commonplaces. In short, Gadamer describes the hermeneutical situation that subtends rhetorical engagement, whereas Nietzsche immerses himself in these engagements as a determined advocate seeking to unsettle traditional discourse.

Despite these contrasts with Gadamer's philosophy, Nietzschean rhetoric is not just an exercise of raw power by an insular speaker who callously manipulates his audience. Nietzsche's rhetorical activity (and his philosophical approach to rhetoric) is not a tool that he wields against inert adversaries, even if his goal is to persuade them of their error rather than to learn from them. He does not just overpower weaker minds with "mere" rhetoric that he marshals in the service of some deeper, subjectively-determined goal. Eugene Garver describes how Aristotle's Rhetoric, which presents rhetoric as an art of character, 
underwrites the reasonableness of this kind of advocacy. ${ }^{127}$ Although Nietzsche cannot demonstrate that the religious fundamentalist is wrong in some absolute sense, he most assuredly believed that his rhetorical engagement with religious fundamentalists could reveal the superior reasonableness of his account. ${ }^{128}$ To be sure, Nietzsche rejects received wisdom about the nature of rationality, but he does not abandon reason.

Nietzsche subverts the narrow conception of reason through his message and his style, constantly challenging his readers with destabilizing and dangerous "maybes." $\mathrm{He}$ is a determined advocate who artfully seeks to persuade his audience to see the merit in claims that pose a radical threat to received wisdom. There is no hermeneutical generosity in his work; no embrace of hermeneutical humility in an open dialogue oriented toward a shared understanding. But this rhetorical approach is not irrational or purely destructive. Gadamer's similar rhetorical emphasis girds Nietzsche's argumentation by describing the hermeneutical situation in which rhetorical engagement occurs. Gadamer's ontological approach should not be mistaken for a refusal to take sides and argue vigorously, but neither should one mistake Nietzsche's vigorous advocacy as a refusal to acknowledge his hermeneutical situatedness. Read together, they illuminate the full dimensions of rhetorical engagement as intersubjective situatedness and reasoned argumentation.

\section{The Critical Power of Tradition}

Nietzsche and Gadamer develop complementary approaches to the rhetorical dimension of human understanding, but rhetorical activities are not free-standing. Both thinkers regard tradition as the backdrop for rhetorical exchanges that provides the resources for critique. Claiming that one of the most productive points of comparison of Nietzsche's and Gadamer's philosophies is the critical power of tradition, Craig Beam argues that

127 Eugene Garver, Aristotle's RhetoriC: An Art of Character (1994).

128 In this regard, see Eugene Garver, Why Should Anybody Listen?: The Rhetoric of Religious Argument in Democracy, 36 WAKE FOREST L. REV. 353 (2001). Garver argues that the modernist prejudice to ban religious argumentation in the public square with the goal of instituting a pluralistic civil society fails to recognize Aristotle's insight that rhetorical advocacy can be reasonable. "One great advantage of the Rhetoric as a way of talking about practical rationality is that it does not presuppose a definition of what is rational, prior to considerations of effective persuasion. Criteria for rationality develop as the art of rhetoric explores the nature of deliberation in its political context." Id. at 36667. 
Nietzsche is the greatest of all counter-examples to the charge that thinking in the light of tradition inevitably biases thought in a conservative direction. Nietzsche, who was both a classicist and a thinker who was profoundly radical, believed that one needed the past, with its exemplars of excellence and untimely otherness, in order to think critically about the present. ${ }^{129}$

This obviously resonates with Gadamer's central theme that all understanding is traditionary understanding, and that engaging with the central texts of a tradition is one of the most important means for remaking the tradition. Although they think through tradition in different ways, both philosophers place great importance on the inevitability of thinking through tradition.

Gadamer's emphasis on traditionary understanding is central to his philosophy. Although many criticize Gadamer for celebrating a stagnant status quo, he uses tradition for precisely the opposite purpose. By characterizing human existence as hermeneutical, Gadamer argues that understanding is never simply a matter of recovery of past truths, but instead emerges in the fusion of horizons that occurs in rhetorical exchanges. Tradition is not a reservoir of fixed truths that transparently answer current questions, Gadamer argues, but rather is the dynamic ground from which those answers are constructed in response to the demands of the present. ${ }^{130}$

Given his scathing critiques of Christianity and moral philosophy, Nietzschean critique would appear to be far removed from Gadamer's hermeneutical cultivation of the resources of tradition. But Nietzsche employs a genealogical method, which by definition is a traditionary inquiry that seeks to understand and reconsider the present by thinking through the past. For example, he acknowledges that Christianity cannot be overcome in the way that we might overcome a dream by awakening to find that it is not "real." We continue to live in a tradition that has been shaped indelibly by Christianity, and the real issue is to interpret where we are in this ongoing tradition. ${ }^{131}$

Genealogical critique is an aesthetic-rhetorical activity that works as a disturbance from within traditional horizons rather than as a commentary from outside a tradition under consideration, and

\footnotetext{
129 Beam, supra note 100 , at 27.

${ }^{130}$ I have explained Gadamer's subtle analysis of tradition in some detail in Francis J. Mootz III, The Quest to Reprogram Cultural Software: A Hermeneutical Response to Jack Balkin's Theory of Ideology and Critique, 76 CHI.-KENT L. REV. 945, 951-60 (2000).

${ }^{131}$ Nietzsche repeatedly states that Christianity is not pure error, and that he is taking issue with the bad interpretations of the Christian heritage that prevailed in the nineteenth century. See, e.g., NIETZSCHE, THE GAY SCIENCE, supra note 33, para. 78, at 132; id. para. 358, at 310; id. at para. 377, at 338. See also supra note 97 and related textual discussion.
} 
the tradition-bound character of this critique is deeply selfreflexive. Nietzsche's On the Genealogy of Morals not only sets out to recover the invention and instantiation of the value judgments "good" and "evil" in human history, it also recollects and reassembles the origins of his argument in his earlier work through allusion, direct reference, and even quotation. The point is vividly made: even the genealogical scholar is enmeshed in an ongoing history, which may itself be the subject of genealogical critique. Nietzsche readily agrees that there is no clean break from the tradition of Christian moralizing that he is criticizing.

But my point will have been taken-there is reason enough, all in all, for our inability, as psychologists of today, to shake off a degree of mistrust towards ourselves... We too are probably still too good for our work, still the victims, the prey, the sick men of this moralized taste of the time, however much we feel ourselves to be those who despise it-it probably infects even us. ${ }^{132}$

The obvious implication of Nietzsche's argument-that the critic cannot speak from outside the tradition he criticizes-motivates Nietzsche's rhetorical and aesthetic disposition within traditionary understandings.

The problem of self-reflexive critique is unavoidable, but not paralyzing. Nietzsche's Third Essay in the Genealogy presents an extended interpretation of the historical emergence of the ascetic ideal and what this ideal means to contemporary society. $\mathrm{He}$ concludes that the ascetic ideal itself is an interpretation designed to give meaning to life in the face of suffering, an interpretation of transcendence and ideality that denies human life. In other words, Nietzsche offers an interpretation (his genealogical critique) to replace another interpretation (Christian morality). But Nietzsche clearly does not regard these interpretations as equally infirm, positioned in a relativistic standoff. Rather, Nietzsche's Third Essay exemplifies the rhetorical engagement in which an aesthetic interpretation proves itself not by reference to timeless truth, but from within the rhetorical context. Nietzsche regards himself as an untimely prophet of an interpretation now emerging to replace the decadence into which asceticism has collapsed, and he vigorously asserts that his interpretation is superior:

[The ascetic ideal promoted by Christianity] "is past, it has conscience against it, it seems to all finer consciences indecent, dishonest, deceitful, feminism, weakness, cowardice-in this rigour, if in anything, we are good Europeans and heirs to Europe's longest and boldest process of self-overcoming." . . .

132 NIETZSCHE, supra note 58, Third Essay para. 20, at 116-17. 
There is no doubt that from now on morality will be destroyed through the coming to consciousness of the will to truth: this is the great drama in a hundred acts which is reserved for Europe over the next two thousand years, the most fearful, most questionable and perhaps also most hopeful of all dramas ... ... We can no longer conceal from ourselves what this willing directed by the ascetic ideal actually expresses in its entirety. . ${ }^{133}$

Nietzsche's certainty does not spring from the perception of truth, but instead is the conviction of one attempting to persuade his readers that his interpretation of tradition is the best interpretation.

Traditionary understandings play a critical role in Nietzsche's writings: not only as object for criticism but as the very medium of critique. He heralds a new day that must remain linked with the night of tradition: Christianity and morality are not defeated by those who stand outside the tradition, but rather through traditionary dynamism that Nietzsche believes cannot be ignored any longer. Nietzschean critique does not represent a denial of the power of tradition, since it is the tradition-in confrontation with the questions posed by present circumstances-that speaks through the genealogical critique. The connection between this critical practice and Gadamer's philosophical analysis of the unavoidable role that tradition plays in all human understanding follows naturally from the previously discussed connections between perspectivism and fusion of horizons, and between rhetorical persuasion and rhetorical exchange. What emerges from these connections are rough outlines of a critical hermeneutics that draw both from Nietzschean critique and Gadamerian hermeneutics.

There are productive linkages that can be drawn between Nietzsche and Gadamer, because of-and not despite-their differences. I have not attempted to subordinate either thinker to the other; that would be counter-productive. My point is that Nietzschean critique and Gadamerian hermeneutics reaffirm and challenge each other in ways that lead to new understandings. To explore these edifying possibilities in greater detail, I turn for guidance to Gianni Vattimo, a philosopher who studied with Gadamer and who considers himself to be a student of Nietzsche. Read in light of my model comprised of Nietzschean critique and philosophical hermeneutics, Vattimo's nihilistic philosophy

133 Id paras. 27-28, at 135-36 (also appearing in FRIEDRICH NIETZSCHE, THE GAY SCIENCE, Book V para. 357 (1882/1887)). 
provides rich detail for my project of developing a critical hermeneutics.

\section{A Hermeneutical Model of Nietzschean CRITIQUe: VATTIMO'S "WEAK THOUGHT"}

I am trying to propose arguments, which, even though they do not claim to be definite descriptions of things as they really are, seem to be reasonable interpretations of our condition here and now. The rigour of post-metaphysical discourse consists in the effort to cultivate an attitude of persuasion without proclaiming a "universal" viewpoint, which is no viewpoint at all, an attitude that is aware of coming from and addressing someone belonging to the same process, of which it has no neutral vision but risks an interpretation. In this case, a neutral reason is not only impossible but literally senseless, as if one were to try to pull out one's eyes in order to see things objectively.

-Gianni Vattimo ${ }^{134}$

Gianni Vattimo exemplifies the model of critical hermeneutics that I am drawing from Gadamer and Nietzsche. Specifically, Vattimo's nihilistic hermeneutics answers the challenges posed to Gadamer by critical legal theorists such as Allan Hutchinson. Under my reading, Vattimo's philosophy finds its strength precisely by drawing on the points of convergence in philosophical hermeneutics and Nietzschean critique ${ }^{135}$ even if at critical junctures Vattimo aligns himself with Nietzsche and Heidegger and against Gadamer. I contend that Vattimo skillfully avoids the aimless nihilism found in caricatures of Nietzsche and the cultural conservatism found in caricatures of Gadamer. After refining my model of critical legal hermeneutics through Vattimo's work, I will employ the model as a touchstone for a critical analysis of the Supreme Court's recent deliberation about gay rights.

Vattimo advocates a "nihilistic" philosophy of "weak thought," in which philosophical thinking accepts its rhetorical role as cultural criticism rather than continuing to assert its power to

134 GianNi VATtimo, BELIEF 46 (Luca D'Isanto \& David Webb trans., 1999) (1996).

135 Vattimo expressly grants "Nietzsche a significant role in that philosophical strand which begins with Schleiermacher, develops through Dilthey and German Historicism, and continues through to Heidegger and post-Heideggerian hermeneutics (i.e., to Gadamer, Ricoeur and Pareyson, to name only the most important figures)," and he predicts "that the study of Nietzsche's philosophy will lead to a more precise definition of the strangely unified character of 'hermeneutics' as a philosophical strand in nineteenthand twentieth-century culture." VATTIMO, supra note 48, at 5-6. 
deliver accurate and perspicacious descriptions of reality. In the post-metaphysical age that Nietzsche helped inaugurate, critique can only be thinking within a cultural horizon as a means of recovering from unproductive prejudices (Verwindung: working through a problem, surviving an ordeal) and can never be an intellectual overcoming of a prejudiced horizon altogether (Überwindung: overcoming an obstacle, moving on). ${ }^{136}$ In this respect, Vattimo continues philosophical thinking in the spirit of Nietzsche's famous aphorism in section 54 of the Gay Science: now that philosophy has "awakened" us to the knowledge that we are still dreaming, all we can do is continue the dream. ${ }^{137}$ By embracing the "weak" character of philosophical thinking and recognizing the provisional nature of its interventions into an unfolding reality, postmodern critical theory embodies Nietzsche's insight that the Enlightenment's quest for total demythologization must fail:

The demythologization of demythologization ... may be taken as the true moment of transition from the modern to the postmodern. This transition occurs in its most philosophically explicit form in Nietzsche. After him, after radical demythologization, the experience of truth simply can no longer be the same as before. ${ }^{138}$

To continue dreaming knowing that you are dreaming, as in the passage from the Gay Science quoted above, is by no means the same as purely and simply dreaming. And so it is with demythologization. If we wish to be faithful to our historical experience, we have to recognize that once demythologization has been exposed as a myth, our relation to myth does not return as naive as before, but remains marked by this experience. ${ }^{139}$

Nietzschean philosophical activity is cultural criticism, a

136 GiANNI VATTIMO, THE END OF MODERNITY: NiHILISM AND HERMENEUTICS IN POSTMODERN CUltuRE 164 (Jon R. Snyder trans., 1991) (1985) [hereinafter VATTIMO, END OF MODERNITY]. Drawing from Heidegger, Vattimo insists: "Precisely this difference between Verwindung and Überwindung can help us to define in philosophical terms the 'post-' in 'postmodernism'." See GIANNI VATTIMO, AFTER CHRISTIANITY (Luca D'Isanto trans., 2002) [hereinafter VATTIMO, AFTER CHRISTIANITY] (arguing that Heidegger recognized that metaphysics "cannot be overcome but only verwundenaccepted, distorted, and continued in ironic directions that are know to be provisional").

137 Gianni Vattimo, The Transparent Society 9 (David Webb trans., 1992) (1989). Nietzsche describes the effect of his insight that there is no essence behind "mere" appearance with the metaphor of awakening to find oneself dreaming: "I suddenly woke up in the midst of this dream, but only to the consciousness that I am dreaming and that I must go on dreaming lest I perish..." NIETZSCHE, THE GAY SCIENCE, supra note 33, Book I para. 54, at 116.

138 VATtimo, THE TRANSPARENT SOCIETY, supra note 137, at 42.

139 Id. at 40. 
Verwindung that necessarily occurs within a plural world from which metaphysical thinking cannot rescue us.

Vattimo's philosophical orientation responds to Hutchinson's critique of hermeneutical philosophy. Hutchinson criticizes hermeneutics for eliding the political dimensions of law either by promoting complacent extensions of traditional understandings, ${ }^{140}$ or by promoting a nihilistic collapse of meaning. ${ }^{141}$ Hutchinson credits Gadamer with attempting to steer a course between these false alternatives, but ultimately concludes that Gadamer reverts to a conservative position that undermines political action. ${ }^{142}$ In the end, though, Hutchinson is left only with a commitment to politics and the paradoxical acknowledgments that political interventions must be historical without being historicist, cannot be directed by a sovereign cogito, and cannot claim to be underwritten by determinate groundings or metaphysical guarantees. Vattimo's philosophy exemplifies the selfunderstanding of political critique in the post-metaphysical age by carrying forward the themes that I identified in reading Gadamer and Nietzsche together, and he demonstrates that Hutchinson's challenge to Gadamer's hermeneutics can be met.

Vattimo's signature insight generally is phrased as a Nietzschean criticism of Gadamer's hermeneutics. Vattimo agrees that all understanding is hermeneutical, but he emphasizes that only Nietzsche fully understands the self-reflexive nature of this claim. Gadamer's hermeneutics urbanizes Heidegger's more radical philosophizing, Vattimo charges, by claiming to deliver an ontological account of human existence that is a "true description of the permanent 'interpretive structure' of human existence."143 Vattimo readily credits Gadamer with persuasively rejecting Habermas's excessive rationalism while also steadfastly refusing to endorse a crude hermeneutic conventionalism, but he contends that Gadamer ultimately presents his philosophical hermeneutics as a metaphysical truth in the tradition of Western philosophizing. This is misguided, Vattimo insists, because if hermeneutics "wishes to be consistent with its own rejection of metaphysics" it can only "present itself as the most persuasive philosophical interpretation of a situation or 'epoch'. . . ."144 In other words, hermeneutic philosophy must acknowledge that the value of hermeneutic

\footnotetext{
${ }^{140}$ See supra notes 11, 14-15 (criticizing James Boyd White).

141 See supra notes 12-13 (criticizing Sanford Levinson).

142 See supra notes 24-32 (criticizing my Gadamerian reading of Justice Souter's opinion in the "right to die" cases).

143 GIANNI VATTIMO, BEyOND INTERPRETATION: THE MEANING OF Hermeneutics For PHILOSOPHY 6 (David Webb trans., 1997) (1994).

${ }^{144} \mathrm{Id}$. at 10 .
} 
arguments is not in revealing bedrock truths, but rather "in being able to establish a coherent picture we can share while waiting for others to propose a more plausible alternative." 145

Vattimo's critique of Gadamer misses the mark when Gadamer is read together with Nietzsche. Vattimo admits that Nietzsche's philosophy appears to be fundamentally at odds with itself by promoting an ontological account of perspectivism, and that this paradox is resolved by construing Nietzsche as a rhetorician rather than a metaphysician. ${ }^{146}$ As I have argued above at some length, it does no violence to Gadamer's texts to read his philosophy in the same manner. Gadamer's ontological claims about the interpretive character of life are rhetorical moves against a dominant myth that no longer effectively organizes experience. Just as Nietzsche announced the death of God as a cultural event that already has taken place, Gadamer announced the death of positivism as a cultural event that already has played itself out. Gadamer, no less than Nietzsche, is attentive to the genealogy of the cultural crisis that he addresses. Truth and Method carefully recounts this genealogy while simultaneously highlighting the suppressed resources of tradition that point the way beyond the unsatisfactory status quo. Vattimo's resolute acceptance of the provisional character of all critical insights uncovers the motivating perspective that drives both Nietzsche and Gadamer, even if they were unable to voice their positions clearly. ${ }^{147}$ Although phrased as a critique of Gadamer, then, Vattimo's hermeneutic nihilism illustrates the value of reading Gadamer and Nietzsche together.

By expressly abandoning any fixed ground for critique, Vattimo's nihilistic philosophy might appear to disable critical theory in the manner that Hutchinson decries. But it is precisely by avoiding sterile metaphysics, Vattimo contends, that his radically nihilistic hermeneutical philosophy embraces the critical and ethical dimensions of thinking. Hermeneutical philosophy must acknowledge that it cannot rise above its historical circumstances, and must embrace its role in generating a Verwindung within our cultural moment:

Hermeneutics can live up to its ethical inclination in an appropriate fashion only be remaining faithful to the instance of

145 Id. at 11.

146 See supra note 67.

147 This is one point where Gadamer's decision not to engage Nietzsche as an interlocutor proves to be a hindrance to Gadamer's efforts, since Nietzsche's paradoxes are hermeneutical in nature. Vattimo's hermeneutic nihilism works through paradoxes that Nietzsche and Gadamer share, even if they come at the problems from different angles. Although Vattimo "sides" with Nietzsche, then, his solution carries equal force in interpreting Gadamer's philosophy. 
historicality. But how? Principally, by thinking of itself not as an ultimately metaphysical descriptive theory of the hermeneutic constitution of existence, but rather as an event of destiny. Hermeneutics must recognize itself as the thought belonging to the epoch of the end of metaphysics, and nothing more. Hermeneutics is not the adequate description of the human condition, which is finally making headway only at a certain point in history, thanks to a particular thinker or a series of fortuitous circumstances. . . . If it theorizes that the experience of truth is belonging and not reflection, it must also say to which epoch, world or provenance it itself as theory belongs. ${ }^{148}$

If . . the "trivial" and weak hermeneutic thesis recognizes itself as belonging, instead of disguising itself as a metaphysical description, then it will see itself as a destiny (a provenance) and will become capable of choice, that is, of morality. Hermeneutics will recognize its destiny, if it understands the nihilistic character of its constitution. ${ }^{149}$

The Verwindung of modernity is a fundametally ironic gesture that rejects any heroic or romantic posture vis-a-vis the Western tradition. The decline of modernity, however, also opens up the opportunity for a new,-but weakly newbeginning for thought, and this is what permits us to consider philosophical nihilism a responsible, rather than a despairing, response to the crisis of the contemporary world. ${ }^{150}$

Because philosophy cannot pretend to dictate answers that are logically derived from essential foundations, it now sees itself as a political and ethical activity, undertaking what Vattimo calls an "ontology of actuality." 151 Hermeneutic philosophy, as an interpretation that seeks to be persuasive under conditions of "contingency, freedom, and risk," 152 generates a critical intervention into political and ethical matters.

Vattimo's approach to critical philosophy problematizes the concept of truth. As he poses the question, Heidegger's radical thinking leads us to ask whether hermeneutics necessarily must be "relativist, anti-intellectualist, irrationalist, and at best traditionalist," 153 since truth is not a correspondence to a fixed reality, nor is it a consensus that emerges from a historical process of enlightenment. Vattimo responds by characterizing truth as

\footnotetext{
148 VATTIMO, supra note 137, at 113.

149 Id. at 114 .

150 Jon R. Snyder, Translator's Introduction to VATTIMO, END OF MODERNITY, supra note 136 , at vi, 1 .

151 Gianni Vattimo, Philosophy, Metaphysics, Democracy, 10 Qui PARLE 1, 5 (Paul Kottman trans., 1997).

152 Id. at 7.

153 VATTIMO, supra note 143, at 75.
} 
dwelling within the groundless abyss of a dynamic tradition, a dwelling that implies "an interpretative belonging which involves both consensus and the possibility of critical activity."154 Vattimo, like Nietzsche and Gadamer before him, characterizes the experience of art as the exemplar of the edifying and challenging experience of truth as dwelling. He rejects classical accounts of aesthetics that depend on "images of integration, harmony and well-roundedness," and which would lead hermeneutical philosophy toward a metaphysical "idealization of the beautiful ethical life." 155 Reclaiming Heideggerian radicalism, he characterizes the experience of art as a disruptive opening, as an event of disclosure and concealment within ongoing interpretations that points the way to a different conception of truth.

Recognizing that hermeneutical philosophy surrenders its radical edge if it becomes nothing more than irrational aestheticism, Vattimo celebrates Gadamer's steadfast attack on aesthetic consciousness and acknowledges the very real danger of aestheticism that might follow from Nietzsche's philosophical performances (and, more recently, Derrida's deconstructive performances). ${ }^{156}$ But Vattimo also rejects Gadamer's implicit claim to provide a phenomenological account that is "founded on an objective, metaphysically true and adequate, description of what hermeneutical experience is really of-which would be an obvious contradiction, given the polemic directed in Truth and Method against every pretence of science and philosophy to provide an 'objective' description of reality."157 The middle course charted by Vattimo parallels my efforts to read Nietzsche and Gadamer together. Reason and critique are intertwined features of Verwindung, not an Überwindung that is accomplished by a sovereign cogito. Reason inheres in the historical effort to reconstruct and project our thrownness. Vattimo concludes that this account of rationality

consists in the fact that, essentially involved in a process (into which we are always-already 'thrown') we always-already know, at least to a certain extent, where we are going and how we must go there. But to orient ourselves, we need to reconstruct and interpret the process in as complete and persuasive a manner as possible. It would be an error to believe that we can jump outside the process, somehow grasping the arche, the principle, the essence or the ultimate structure. Rationality is

\footnotetext{
154 Id. at 82 .

155 Id. at 87.

156 Id. at $99-101$.

157 Id. at 103.
} 
simply the guiding thread that can be comprehended by listening attentively to the messages of the Schickung. Both the theoretical choice for hermeneutics and the specific choices of our interpretive activity can be justified by argumentation on this basis. ${ }^{158}$

Hermeneutics acknowledges that reason is not limited to scientific argumentation, but neither is it a pure aestheticism; rather, reason just is the movement of interpretation and critique that later comes to regard itself as an object in hermeneutical philosophizing. ${ }^{159}$

158 Id. at 109

$159 \mathrm{Id}$. at 111. Vattimo argues that Nietzsche connects science and art as dispositions that attend to the constructed nature of existence.

In a more developed form the interest and the pleasure comes to life in [the scientist], which art has taught us over the centuries, namely to observe life in all its forms. With this interest and pleasure we counter the development of errors, from which the world of appearances arises, in those moments when we raise ourselves above them. This long education through art has prepared the ground for science and the free spirit, and both must therefore be grateful to art.

VATTIMO, supra note 48, at 55. See generally supra note 48.

This insight undermines Vattimo's sharp criticism of Gadamer's celebration of art as promoting Erfahrung (a life-shaping experience that affects one's ongoing interpretations of the world) rather than merely Erlebnis (a discrete and immediate experience that cannot be fully elaborated through exegesis). See VATTIMO, END OF MODERNITY, supra note 136, at 121-28, and VATTIMO, supra note 143, at 58-74. Vattimo argues that Gadamer courts a neo-humanist philosophy of history that elides the more radical nihilistic challenges of Nietzsche and Heidegger. See VATTIMO, END OF MODERNITY, supra note 136, at 114-15. However, Gadamer well recognizes the "shock" by which art can pull one away from prejudices with critical understanding, and he does not celebrate an historically unfolding humanism. Gadamer's point is that the fundamental challenge posed by great art is challenging because it is at once intimately present to the individual yet also unyielding to simplistic absorptions into the individual's pre-existing horizon precisely because the destabilizing challenge of art is forward looking. See GADAMER, supra note 1, at 55-81, 346-62 (contrasting Erlebnis and Erfahrung). Gadamer insists that the meaning of art is always a surprise in which everything

familiar is eclipsed. To understand what the work of art says to us is therefore a self-encounter. But as an encounter with the authentic, as a familiarity that includes surprise, the experience of art is experience in a real sense and must master ever anew the task that experience involves: the task of integrating it into the whole of one's own orientation to a world and one's own self-understanding.

$\cdots$

The intimacy with which the work of art touches us is at the same time, in enigmatic fashion, a shattering and a demolition of the familiar. It is not only the "This art thou!" disclosed in a joyous and frightening shock; it also says to us;

"Thou must alter thy life!"

Hans-Georg Gadamer, Aesthetics and Hermeneutics, in PHILOSOPHICAL HERMENEUTICS, supra note 122, at 101-02, 104 . Art demonstrates in particularly vivid ways the intertwining of the deconstructive and reconstructive, underscoring that we cannot attempt to achieve a kind of pure critique (or experience of critique, in the manner of experience designated by Erlebnis) that is not part of the ongoing myth-making by which life proceeds. Gadamer's rejection of aesthetics in favor of the experience engendered by the work of art connects with Nietzsche's demythologization through the (unavoidable) lived experience of myth. It is celebrating discrete nihilistic breaks and ruptures that threatens to inspire humanistic and romantic tendencies, rather than Gadamer's 
Vattimo's critique of religion provides the most cogent example of his conception of philosophy as cultural criticism. By demythologizing objectivism, Vattimo observes, nihilistic philosophy lends fresh plausibility to religion at a time when the dissembling forces of globalization generate a longing for something vital as an antidote to the emptiness of modernity. ${ }^{160}$ Claiming that the "end of metaphysics and the death of the moral God have liquidated the philosophical basis of atheism," Vattimo argues that belief suddenly is possible again. ${ }^{161}$ Weak thought liberates religion from God, which is to say that it liberates religion from the philosophical constructions of God as sovereign deity, metaphysical truth, and so on, and makes belief plausible.

But Vattimo claims an even stronger connection between religion and his philosophy: "Hermeneutics can be what it is-a non-metaphysical philosophy with an essentially interpretive attitude towards truth, and thus a nihilistic ontology-only as heir to the Christian myth of the incarnation of God." ${ }^{162}$ This paradoxical and surprising situation, in which religion returns to the forefront of social life, is not an ontological necessity but rather a historical development.

Perhaps not by its essential nature, but de facto,... religion comes to be experienced as a return. In religion, something that we had thought irrevocably forgotten is made present again, a dormant trace is reawakened, a wound re-opened, the repressed returns and what we took to be an Überwindung (overcoming, realization and thus a setting aside [of religion by philosophy]) is no more than a Verwindung, a long convalescence that has once again come to terms with the indelible trace of its sickness. ${ }^{163}$

Vattimo chronicles the return of religion in the wake of the death of God; arguing that nihilistic hermeneutical philosophy embodies the kenosis of the divine and opens the possibility for realizing (in

acknowledgment that the experience of art is part of an ongoing self-understanding that always lurks behind our consciously-directed critical postures.

160 Gianni Vattimo, The Trace of the Trace, in RELIGION 79-94, 80-81 (Jacques Derrida \& Gianni Vattimo eds., David Webb trans., 1998). See also VATtimo, supra note 143, at $42-57$.

161 VATtimo, AfTER Christianity, supra note 136, at 17. In other words, the "fact is that the decline of the great metanarratives ... has put an end, too, to the strong reasons for philosophical atheism." Id. at 86.

162 VATTIMO, supra note 143, at 54. Vattimo acknowledges the "paradox of having recovered Christianity-in the form of believing that I believe-through Nietzsche and Heidegger," VATTIMO, AFTER CHRISTIANITY, supra note 136, at 3, but reaffirms that Heidegger's response to a call can be interpreted as a response to the Judeo-Christian tradition.

163 Vattimo, supra note 160 , at 79. 
a new way) the central Christian principle of charity. ${ }^{164}$

The return of religion exemplifies Nietzsche's doctrine of the eternal return, but Vattimo stresses that we can and should joyously embrace this return as nihilistic practitioners of the gay science, in which the cycle of the "same" is transformed. The doctrines of "will to power" and "eternal recurrence of the same" do not drive Nietzsche to nihilistic despair. Vattimo emphasizes that Nietzsche's philosophy points beyond deconstructions and refutations and toward defining the good temperament and lightness of being that should follow the acknowledgment of the eternal recurrence: ${ }^{165}$

Even when Nietzsche concedes that the doctrines of Will to Power and Eternal Recurrence are themselves only interpretations, he does not in fact believe that they have the same status as any old interpretation: for instance, he does not believe that the interpretation called Will to Power is on a par with the one called "Christian morality". Perspectivismanother term Nietzsche uses to characterize the thought of his final creative period-does not in fact mean that the theory itself, which maintains a plurality of perspectives, should not and must not make a selection from among these perspectives. The theory must at least decide between itself and the many other interpretations available.

The criteria for making such a decision, which Nietzsche cites again and again, are of a "physiological" nature: strengthweakness, health-sickness, as well as the related ideas of creativity-"ressentiment" and active-reactive. Strictly speaking, the rejection of metaphysics on account of the errors underlying it cannot be attributed to Nietzsche, since according to him error is vital to life and since in his eyes there is no "truth" which would be "more valuable" than error, and to which one could appeal in order to get beyond error. When morality's metaphysical lie is exposed by the changes in the conditions of life and of morality's logic and when God "dies", not to acknowledge this is more a sign of physiological degeneration and poor health than is the refusal to acknowledge a truth consisting of facts. Strength and weakness, health and sickness are the only criteria that Nietzsche has left after unmasking metaphysics. ${ }^{166}$

Gadamer's philosophical legacy proves to be important for Vattimo at this point, even if in a subterranean manner. ${ }^{167}$ During

164 See generally VATTIMO, supra note 134

165 VATTIMO, supra note 48, at 82-86.

166 Id. at $126-27$.

167 In his contribution to a Festschrift in celebration of Gadamer's one-hundredth birthday, Vattimo acknowledges that the "current configuration" of hermeneutics "is mostly the result of Gadamer's work." Gianni Vattimo, Gadamer and the Problem of 
his long career, Gadamer emphasized that moving beyond the Enlightenment's "prejudice against prejudice" does not mean that one is fated to accept an endless nihilistic confrontation between equally prejudiced beliefs. Instead, as exemplified in the experience of art, hermeneutical engagement shatters the interpreter's prejudiced horizon in a manner that permits her to gain perspective on certain "unproductive prejudices" and to move forward. This contemplative attitude, this good conscience, is an openness to the perspectivity of the Being and the relinquishment of the certainty of metaphysical schemas. Gadamer believes that this can be achieved only through a willingness to enter a conversation and to learn from the other (person, text, or culture) in a playful dialogic encounter that is not methodologically scripted. It is precisely this social dimension of reason that augments Nietzsche's work and highlights the possibility and genesis of Verwindung after we have awakened to realize that the dream of a theoretical and monological Überwindung is impossible.

Vattimo's philosophy exemplifies the model of critical hermeneutics that I derived from reading Nietzsche and Gadamer together. Critical theory is a movement within a prejudiced horizon rather than overcoming one's horizon. Gadamer's hermeneutical philosophy is best read not as advocating reverence for traditional understandings, but rather as acknowledging that tradition is a linguistically structured and contested medium through which understanding takes place. Nietzsche's critical philosophy is best read, not as claiming to have discovered bedrock reality through philosophical analysis, but rather as acknowledging that reality is hermeneutically structured and therefore dynamic rather than stable. Vattimo offers an approach to critical theory that brings together these insights and points the way toward rethinking the role of critical legal theory.

Ontology, in GADAMER's CENTURY: ESSAYS IN HONOR OF HANS-GEORG GADAMER 299-306 (Jeff Malpas et al. eds., Stefano Franchi trans., 2002). However, Vattimo urges a more productive reading of Gadamer's work that rejects the tendency toward a metaphysical description of an interpretive reality and embraces an "ontology of actuality" in which hermeneutical philosophy acknowledges that it is part of a play of interpretations that has effects and ethical significance. Id. at 305-06. My thesis is that Gadamer has empowered Vattimo to see this reading of Gadamer's work, and that Vattimo's attention to Nietzsche need not be viewed as being at odds with his orientation within Gadamerian hermeneutics. 


\section{The Gay Science of Legal Hermeneutics: Critique AND THE LEGAL TREATMENT OF HOMOSEXUALS}

The Gay Science can be read as a treatise on law and those who would write against the law.

$\ldots$

A Gay Science would carry forward the passion of Critical Legal Studies, but in a different way. It would accept that life in law is defined by principles and rules that determine and restrain interpretative activity and political possibility, but it would see this as the challenge to the joyous interpreter to develop counter strategies within the law. A Gay Science would insist that the only authenticity is that of a mood, of a sensibility that informs the world.-

\section{Adam Gearey ${ }^{168}$}

What conclusions about critical legal theory can be drawn from my readings of Gadamer, Nietzsche and Vattimo? To this point my exegesis has been abstracted from legal practice. At this level of generality it is easy to understand that these thinkers reject the urge to engage in modernist "strong" theory, but it is difficult to discern what it might mean for pursuing the possibilities of "weak" critical theory within law. By bringing my discussion to bear in the practical context of a legal dispute, however, it is possible to locate important lessons for legal theorists. I explore the implications of my Nietzschean-Gadamerian model of critical legal hermeneutics through a discussion of three United States Supreme Court cases that have grappled with the constitutional issues that circle around the question of the legal status of gays and lesbians. My thesis is that a critical legal hermeneutics provides not only substantial descriptive clarification of these cases, but also inspiration for effective critical intervention. Critical insight is possible even if (or, more precisely, because) my model of critical legal hermeneutics does not pretend to offer an interpretive methodology that delivers unimpeachably correct answers to specific legal questions. Due to the high profile nature of these cases and the relative degree of self-reflection apparent in the judicial opinions, these cases provide strong evidence supporting the model of critical legal hermeneutics on their own terms, and do not require much reading against the grain.

168 Adam Gearey, We Fearless Ones: Nietzsche and Critical Legal Studies, 11 LAW \& CRITIQUE 167, 169, 184 (2000). 
In 1986, the Court held in Bowers v. Hardwick, ${ }^{169}$ a 5-4 decision, that a Georgia statute criminalizing sodomy did not violate the United States Constitution when it was applied to an adult man who engaged in consensual sexual activity with another man in his bedroom. The majority made clear that Georgia could choose to criminalize acts that it determined to be immoral. Ten years later, in Romer v. Evans, ${ }^{170}$ the Court again decided by a 5-4 margin that a Constitutional referendum enacted by the citizens of Colorado to preclude municipal measures designed to prohibit discrimination against homosexuals in public accommodations was unconstitutional. The Court found that the referendum was motivated by animus against gays and lesbians and was not rationally related to any legitimate state purpose. Finally, just four years after Romer, the Court again voted 5-4 in Boy Scouts of America v. Dale ${ }^{171}$ that a New Jersey anti-discrimination statute prohibiting discrimination on the basis of sexual orientation was unconstitutionally applied to prohibit the Boy Scouts from refusing to allow a gay man to serve as a scout leader. The Court concluded that the Boy Scouts organization has a First Amendment right of association to exclude homosexuals from its leadership positions.

The tangled history of these three cases has received extensive scholarly attention, but I do not intend to offer a detailed analysis of the legal rationales in the various opinions and in the numerous scholarly assessments. My goal is to show that the legal reasoning exhibited in these cases is consistent with my model of critical legal hermeneutics, and also that these cases illuminate the role that critical legal theory can play under this model. My discussion is schematic and suggestive, therefore, rather than doctrinal. It is precisely by resisting the urge to declare the truth of the matter, to demarcate methodologically permissible and impermissible legal interpretations, that enables critical legal hermeneutics to gain purchase beyond the artificial realm of the ivory tower. My discussion of these cases shows the power that critique holds as an interpretation offered within a play of interpretations, and rejects the belief that theorists can or should attempt to rise above interpretive activity to prescribe correct interpretations.

I begin by contending that these cases clearly exhibit the rhetorical nature of legal argumentation that is revealed by reading Gadamer and Nietzsche together. In particular, they exemplify the rhetorical lesson that how one frames a question

\footnotetext{
169478 U.S. 186 (1986)

170517 U.S. 620 (1996).

171530 U.S. 640 (2000).
} 
largely determines the answer that one generates. ${ }^{172}$ The seemingly mundane and technical observation that adroitly framing the question is an important part of argumentation, often taught to students in advocacy courses as a technique for increasing their ability to be persuasive in pursuit of the predetermined goal of victory for their client, in fact reveals something about the nature of legal argumentation that runs much deeper than superficial rhetorical strategizing. Nietzsche's dramatic efforts to persuade his readers complements Gadamer's ontological focus on the dialogic nature of human understanding. Framing the question in issue is not a matter of demarcating the perspicacious features of the world-in-itself that can later be investigated, but rather is the activity of rhetorical engagement that provides us with a world in the first instance.

In Bowers, Justice White's analysis and conclusion for the majority follow naturally from his starting point that the issue presented was "whether the Federal Constitution confers a fundamental right upon homosexuals to engage in sodomy and hence invalidates the laws of the many States that still make such conduct illegal and have done so for a very long time." ${ }^{173}$ Having framed the question in this way, the Court is able to distance itself from the issue of "whether laws against sodomy between consenting adults in general, or between homosexuals in particular, are wise or desirable," 174 and to proceed by demonstrating the obvious point that the Constitution cannot be fairly read within the American Constitutional tradition as conferring an affirmative right to engage in homosexual sodomy. The tenor of the opinion is that of a reluctant political actor who must respect the division of judiciary and legislature, suggesting that although the Court may disagree with the impulses of the Georgia legislature it does not have a legitimate political role to play in such matters. The holding naturally follows: because laws criminalizing sodomy are rooted in ancient moral values, they are the rational products of legislative acts that cannot fairly be said to contravene fundamental liberties that are deeply rooted in American legal and social traditions. ${ }^{175}$

172 Cf. Michel Meyer, Rhetoric, LANGuage, AND ReAson (1994) (advocating an approach to philosophy that he characterizes as "problematology," which is devoted to investigating the central role played by questions in reasoning and overcoming the traditional privileging of answers as the focus of philosophy).

173 Bowers, 478 U.S. at 190.

174 Id.

175 Id. at 191-93. Chief Justice Burger's infamous concurring opinion emphatically underscores the narrow holding that "there is no such thing as a fundamental right to commit homosexual sodomy," id. at 196 (Burger, C.J., concurring), but makes it more 
Justice Blackmun's dissenting opinion attacks the majority's formulation of the question directly and caustically:

A fair reading of the statute and of the complaint clearly reveals that the majority has distorted the question this case presents.

$\ldots$

... The Court claims that its decision today merely refuses to recognize a fundamental right to engage in homosexual sodomy; what the Court really has refused to recognize is the fundamental interest all individuals have in controlling the nature of their intimate associations with others.

...

... I can only hope that ... the Court soon will reconsider its analysis and conclude that depriving individuals of the right to choose for themselves how to conduct their intimate relationships poses a far greater threat to the values most deeply rooted in our Nation's history than tolerance of nonconformity could ever do. ${ }^{176}$

Blackmun's challenge openly embraces the rhetorical character of decision-making and expressly re-frames the question as whether time-honored moral condemnations of the majority of citizens outweigh dynamic constitutional principles of privacy and individual self-determination. The dissent steps back from the specific facts of the case involving consensual sex between gay men, and constructs the issue in terms of the scope of privacy for intimate relations generally. The fact that the question comes to the court in the context of an arrest of two gay men ostensibly does not figure in this approach. ${ }^{177}$

The Bowers case provides a stark reminder of the nature of legal argumentation. It is easy to lampoon the myth that legal conclusions are generated deductively by placing the facts under a conceptual rubric of legal principles, but it is easy to miss the deep critique that the facts, legal principles and analytical moves all are rhetorically constructed. The majority and dissent both strive to prevent Bowers from being a case about an abstract conception of gay rights, much to the chagrin of several of the Justices on each side of the case. The primary opinions on both sides of the decision transparently create the legal disputes that they are

clear that he sees no role for the court to "cast aside millennia of moral teaching." Id. at 197.

176 Id. at 200, 206, 214 (Blackmun, J., dissenting).

177 The separate dissenting opinion authored by Justice Stevens focuses on the selective enforcement of the statute against gays and directly takes up the question of the constitutionality of targeting disfavored groups through application of broadly worded statutes. Id. at 219 (Stevens, J., dissenting) ("A policy of selective application must be supported by a neutral and legitimate interest-something more substantial than a habitual dislike for, or ignorance about, the disfavored group."). 
prepared to countenance and decide. Bowers quite expressly demonstrates that the law is not a resource for making decisions when disputes arise, but rather is the activity of framing disputes and then making judgments.

The rhetorical reality of legal decisionmaking is no less apparent in the other two cases. In Romer, Justice Kennedy carefully refused to grant protected class status to gays and lesbians that would support application of a "strict scrutiny" standard, finding instead that the constitutional referendum failed-in fact, "defied"-the lesser constitutional requirement that legislation bear a "rational relation" to legitimate state interests. ${ }^{178}$ But even by framing the question in this manner, he could not justify the majority's holding without concluding, at a minimum, that legislation having no purpose other than disenfranchising disfavored groups as an expression of the animus of the majority of citizens is unconstitutional. ${ }^{179}$ Justice Scalia's characteristically scathing dissent cut through this circumlocution with a determined logical rigor: given the unchallenged Bowers holding that a state may criminalize homosexual activity, he argued that it must be the case that a state may enact laws that merely disfavor homosexual conduct by prohibiting municipalities from conferring favored status on individuals "because of their homosexual conduct."180 Although Kennedy and Scalia openly spar over the legitimacy of legislatively targeting gays and lesbians, in the end they propose competing general characterizations of the question presented by the case. Kennedy declares the Colorado constitutional amendment unconstitutional because it precludes

\footnotetext{
178 Romer v. Evans, 517 U.S. 620, 625, 631-32 (1996) (contrasting the "strict scrutiny" review by the Colorado Supreme Court with the "rational relation" review employed by the Court).

179 Justice Kennedy reasoned:

First, the [constitutional] amendment [enacted by referendum] has the peculiar property of imposing a broad and undifferentiated disability on a single named group, an exceptional and, as we shall explain, invalid form of legislation. Second, its sheer breadth is so discontinuous with the reasons offered for it that the amendment seems inexplicable by anything but animus toward the class it affects; it lacks a rational relationship to legitimate state interests.

...

A law declaring that in general it shall be more difficult for one group of citizens than for all others to seek aid from the government is itself a denial of equal protection of the laws in the most literal sense.

... We must conclude that Amendment 2 classifies homosexuals not to further a proper legislative end but to make them unequal to everyone else. This Colorardo cannot do. A State cannot so deem a class of persons a stranger to its laws.

Id. at 632, 633, 635 .

${ }^{180}$ Id. at 644 (Scalia, J., dissenting).
} 
democratic political activities by a minority group for no reason other than animus against the group. In contrast, Scalia argues that the case questions the limits of judicial power to overturn democratic recognitions of "traditional American moral values," arguing that constitutionally precluding those who engage in morally disfavored activity from gaining "special protections" under municipal anti-discrimination laws reflects political decisions removed from the Court's purview.

The same situation holds true in Dale, in which Chief Justice Rehnquist begins his analysis by phrasing the question as whether a state may constitutionally prevent an organization from espousing views about the morality of homosexuality. ${ }^{181}$ Rehnquist concludes that requiring the Boy Scouts to retain a gay scout leader is tantamount to interfering with the organization's message that homosexuality is not "morally straight," and that the Court "cannot doubt that the Boy Scouts sincerely holds this view." 182 Justice Stevens begins his dissent by undermining Rehnquist's transparent assumption, asking whether an organization may avoid application of state anti-discrimination statutes simply by declaring that its aversion to having gay scout leaders is part of the organization's shared goal in disapproving of homosexuality. ${ }^{183}$ His opinion carefully reviews the facts of record to conclude that the Boy Scouts organization "is simply silent on homosexuality. There is no shared goal or collective effort to foster a belief about homosexuality at all-let alone one this is significantly burdened by admitting homosexuals." 184 Because Justice Stevens quite openly declares that the majority feeds on outmoded prejudices against gays and lesbians to support base prejudice by the Boy Scouts unrelated to any genuine expressive goal, ${ }^{185}$ Justice Souter wrote separately for the other three dissenters to insist that the current social acceptability of the message purportedly espoused by the group is irrelevant to the analysis. ${ }^{186}$ Once again, the

181 Boy Scouts of America v. Dale, 530 U.S. 640, 647-48 (2000).

182 Id. at $651,653$.

183 Id. at 683-84 (Stevens, J., dissenting).

184 Id. at 684

185 Id. at 688-95 (Stevens, J., dissenting). Stevens notes that the Boy Scouts might have a different case if Dale repeated his advocacy for gay rights as part of a college organization in the context of his leadership role with the Scouts, or if the Boy Scouts determined to expel any person-regardless of that person's sexual orientation-who openly advocated for gay rights. Instead, he concludes, the "only apparent explanation for the majority's holding... is that homosexuals are simply so different from the rest of society that their presence alone-unlike any other individual's-should be singled out for special First Amendment treatment," id. at 696, a perspective that he later labels an "atavistic opinion[]," id. at 699.

${ }^{186}$ Id. at 701 (Souter, J., dissenting). 
rhetorical framing at work in these opinions shapes the relevant facts, the categorization of the legal issue, the analysis, and the conclusion. It is manifest that there are myriad ways in each of these cases in which these elements could be framed differently.

These cases illustrate that it is in rhetorical engagement that perspectives are revealed and horizons are fused. Nietzsche's rhetorical advocacy and Gadamer's investigation of the rhetorically-secured bonds of community are both necessary in understanding the dynamic of legal reasoning as exhibited in these cases. It takes hardly any effort to point out the strategies invoked by Justices on both sides of each case in their search for the grounds of persuasion. But if law is nothing more than rhetorical activity in this sense, there is reason to fear that the caricatures of Nietzsche's perspectivism might gain purchase and lead to nihilism. Gadamer's philosophy provides the resources to see the degree to which this rhetorical advocacy necessarily is founded in community, within which the variegated horizons that comprise a tradition might fuse in the never-complete and always-provisional activity of understanding. Gadamer does not endorse a simpleminded idealism, in which vigorous advocates suddenly reach a shared answer that causes their differences to disappear effortlessly. Instead, he recognizes that the activity of persuading is always predicated on understanding one's audience, which means that one's position is pre-figured and then altered in the course of persuasive discourse. In short, the rhetorical character of legal reasoning exemplifies the need for Nietzsche's perspectival wariness and Gadamer's hermeneutical charity.

These themes are particularly vivid in the awkward effort by the Justices in Romer to accommodate not only the preceding tradition generally, but the Bowers precedent specifically. Justice Kennedy's majority opinion does not mention Bowers, ${ }^{187}$ although the case clearly loomed large in the minds of all concerned. He carefully distinguishes singling out insular groups for political disestablishment based on personal characteristics from the criminalization of sodomistic acts. But of course, this merely recalls the initial reluctance of the Bowers Court to countenance the fact that a criminal statue facially applicable to sodomy by any two persons in fact was being used by the state as a means for selectively harassing gay men. ${ }^{188}$ And Justice Scalia's dissent is too

187 Justice Scalia declares that the "case most relevant to the issue before us today is not even mentioned in the Court's opinion," and then declares the Bowers holding to be "unassailable, except by those who think that the Constitution changes to suit current fashions." Romer v. Evans, 517 U.S. 620, 640-41 (1996) (Scalia, J., dissenting).

188 Justice Stevens hints at this dimension of the case after noting that the state 
gleeful in equating the cases on the grounds that the legitimation of anti-gay beliefs in Bowers necessarily translates to what he contends is a much less drastic expression of the same anti-gay beliefs that is under review in Romer. ${ }^{189}$ While Justice Kennedy's opinion in Romer suggested that there was no rational basis for precluding political activity at the municipal level to prevent discrimination against gays and lesbians, the premise of Bowers was that it is entirely rational for a state to enact moral condemnations into law. As Justice White concluded in Bowers, the law "is constantly based on notions of morality, and if all laws representing essentially moral choices are to be invalidated under the Due Process Clause, the courts will be very busy indeed."190

In addition to the rhetorical character of legal reasoning, these cases also reveal the dynamic and polysemic character of the legal tradition that fosters critical insight even in the absence of an invariant criterion of judgment. In other words, the practice of rhetorical elaboration in legal practice necessarily carries forward and has continuing effects, but these effects are simultaneously stabilizing and de-stabilizing. Phrased in Gadamerian terms, rhetorical elaboration is always pre-figured by history and itself has a history of effects, but rhetorical engagement does not unfold

conceded that application of the statute to married couples would be unconstitutional and that it in fact was declining to continue the prosecution of the named defendant, Michael Bowers. Bowers v. Hardwick, 478 U.S. 186, 220 n.13 (1986):

Indeed, at this [early] stage [of the litigation], it appears that the statute indiscriminately authorizes a policy of selective prosecution that is neither limited to the class of homosexual persons nor embraces all persons in that class, but rather applies to those who may be arbitrarily selected by the prosecutor for reasons that are not revealed either in the record of this case or in the text of the statute.

Id. Subsequent details about the facts leading to the arrest of Michael Hardwick confirm that he was targeted for arrest as a result of anti-gay animus that could be officially expressed by virtue of the broad and facially neutral criminal prohibition against sodomy. See Thomas J. Coleman, Jr., Disordered Liberty: Judicial Restrictions on the Rights to Privacy and Equality in Bowers v. Hardwick and Baker v. Wade, 12 T. MARSHALL L. REV. 81, 89-92 (1986) (providing a succinct description of the events leading to Hardwick's arrest as related by Hardwick in an interview).

189 Scalia openly describes the context of the dispute as a "Kulturkampf" in which the Court can play no role after Bowers:

If it is constitutionally permissible for a State to make homosexual conduct criminal, surely it is constitutionally permissible for a State to enact other laws merely disfavoring homosexual conduct.... And a fortiori it is constitutionally permissible for a State to adopt a provision not even disfavoring homosexual conduct, but merely prohibiting all levels of state government from bestowing special protections upon homosexual conduct. ...

... If it is rational to criminalize the conduct, surely it is rational to deny special favor and protection to those with a self-avowed tendency or desire to engage in the conduct.

Romer, 517 U.S. at 641-42 (Scalia, J., dissenting).

190 Bowers, 478 U.S. at 196. 
in a teleological or even determinant manner. The law is always in flux, particularly at those moments when judges claim to fix the law by their decision in a particular case.

Returning to the cases under discussion illuminates this dimension of legal reasoning. It would be folly to read these cases in an effort to discern a logical unfolding of doctrine. The ground keeps shifting-first criminal law, then rights of democratic participation, and finally freedom of speech-and these different contexts determine much about the case analysis in a way that precludes a belief that the Court is addressing the general question of "gay rights." Although several justices disavow what they perceive to be the Court's refusal to address the "real question," there simply is no "pure, unadulterated" question to be answered. The shifting doctrinal and historical contexts of these cases open different angles on the seemingly singular question, and it is in this dynamic that critical distance becomes possible.

Justice Scalia most effectively criticizes the Court's manner of rhetorically narrowing the issues involved in the cases and makes a plea that the Court acknowledge the real issue. In his dissent in Romer, Scalia backs away from the doctrinal question before the court and describes the case in terms of what he contends is really going on: the citizens of Colorado did not act out of animus (having recently repealed anti-sodomy criminal statutes), but rather to express moral disapproval, "the same sort of moral disapproval that produced the centuries-old criminal laws that we held constitutional in Bowers." 191 In response to political success by gays and lesbians at the local level to enact provisions that reflect an acceptance of their sexual orientation, Scalia argues, Colorado enacted the Constitutional amendment to reaffirm the state's rejection of homosexuality. ${ }^{192}$ The Court is confronting a political battle over the moral limits to behavior in society, a political battle that the Court should not enter under the guise of Constitutional adjudication. Scalia concludes:

The Court today ... employs a constitutional theory heretofore unknown to frustrate Colorado's reasonable effort to preserve traditional American moral values.

$\cdots$

When the Court takes sides in the culture wars, it tends to be with the knights rather than the villeins-and more

191 Romer, 517 U.S. at 644 (Scalia, J., dissenting).

192 "I do not mean to be critical of these [municipal] legislative successes [by gays and lesbians]; homosexuals are as entitled to use the legal system for reinforcement of their moral sentiments as is the rest of society. But they are subject to being countered by lawful, democratic countermeasures as well." Romer, 517 U.S. at 646 (Scalia, J., dissenting). 
specifically with the Templars, reflecting the views and values of the lawyer class from which the Court's members are drawn. ... ... Striking [the amendment] down is an act, not of judicial judgment, but of political will. ${ }^{193}$

Scalia diagnoses the open questions behind the rhetoric, so to speak, even as he disclaims the Court's competence and authority to speak to these questions.

But Scalia remains blind to the constitutive effects of the judicial discourse that he declares to be disconnected from the political matters in issue. When Scalia found himself in the majority a few years later in Dale, he did not write separately despite the obvious irony. His deference in Romer to the political right of Colorado citizens to instantiate their moral beliefs against gays and lesbians in state law is not similarly extended to the political right of New Jersey citizens to instantiate their moral condemnation of discrimination against gays and lesbians into state law. To suggest that the latter political activities are subject to overriding constitutional principles of free speech is to forget that Romer similarly held that the former political activities are subject to equally important constitutional limitations. This is not to say that Scalia's position in the two cases are contradictory, just that his "Kulturkampf" analysis is insufficient to get at what is "really going on," because he simplistically views these cases as nothing more than political referenda on the social acceptability of homosexuality. The first amendment context in which Dale was decided has an enormous effect on the reasoning, as the Court labored under the (incredibly fragile) conceptual framework of its free expression jurisprudence generally, and the Hurley precedent more specifically. ${ }^{194}$

Legal resolution of the status of gays and lesbians in contemporary American society cannot be charted in advance by legal theorists "in the know," who then patiently prod the less perceptive among them until reality catches up to their superior insight. The complex legal situation is rhetorically negotiated in myriad ways that only appear to be definitively established in the authoritative opinions of the highest court in response to a certain "logic of development," but which in fact is reconstituted and extended in unpredictable ways. The next dramatic event in this ongoing process will occur in March 2003 when the Supreme Court again decides whether a state may constitutionally criminalize the

\footnotetext{
193 Id. at 651-53 (Scalia, J., dissenting).

194 In Hurley v. Irish-American Gay, Lesbian and Bisexual Group of Boston, Inc., 515 U.S. 557 (1995), the Court held that organizers of a private St. Patrick's Day parade could not be compelled under state public accommodations law to allow the participation GLIB.
} 
sexual intimacy of gays and lesbians. ${ }^{195}$ Although Lawrence $v$. Texas involves a factual situation similar to that in Bowers, it is also clear that Lawrence is an entirely different case arising within an entirely different setting. A brief examination of the different posture of the Lawrence case reveals how the rhetorical and hermeneutical activities of legal practice provide openings for critical reconstructions of that practice.

In Lawrence, two men pleaded nolo contendere to a criminal charge under Texas's "Homosexual Conduct" law, which bans "deviate sexual intercourse" with another person of the same sex. ${ }^{196}$ Unlike Bowers, in which the State of Georgia had dropped the criminal charges before trial, the defendants in Lawrence were convicted of the offense after their constitutional challenges to the statute failed, and each defendant was required to pay a fine and court costs. ${ }^{197}$ In the Petition for Certiorari, the defendants emphasize that they have experienced the very real harm of a criminal conviction, including reputational harm, disqualification from practicing certain professions, and having to register as convicted sex offenders under the laws of four states. ${ }^{198}$ This case represents the natural consequence of Bowers, as the hypothetical potential for suffering a criminal conviction is now a criminal conviction on appeal.

There is a significant difference at the doctrinal level as well. Unlike the Georgia statute in Bowers, the criminal charge of "Homosexual Conduct" specifically applies only to conduct between members of the same sex, and does not criminalize the exact same (consensual, non-commercial) conduct if a man and woman engage in that conduct. As a result, the legal challenge is framed as a violation of the Equal Protection clause, rather than a violation of Substantive Due Process. This doctrinal distinction yields a new set of arguments and range of justifications that will cast the case in a different light than Bowers. ${ }^{199}$ Subsequent

195 Lawrence v. Texas, 123 S. Ct. 661 (2002) (Mem. op. granting cert.).

196 Lawrence v. Texas, 41 S.W.3d 349, 350 (Tex. App. 2001) (noting the defendants' conviction under TEX. PEN. CODE \$21.06, which is entitled, "Homosexual Conduct").

${ }^{197}$ Petition for Writ of Certiorari, at 6, Lawrence v. Texas, 123 S. Ct. 661 (2002) (No. 02-102).

198 Id. at $12-13$.

199 Several Justices of the Texas Court of Appeals debated the significance of this distinction. Justice Fowler concurred with the majority's determination that Bowers plainly established the constitutionality of the statute in question, notwithstanding the fact that Bowers analyzed the Georgia precedent under the Due Process Clause, arguing that the "rational basis test. . . does not differ depending on whether it is applied in a "due process' or an 'equal protection' context." Lawrence v. Texas, 41 S.W. 2 d at 366 (Fowler, J., concurring). In contrast, the dissenting opinion stressed the distinctions between equal protection and due process review:

The Due Process clause has frequently been understood as an effort to restrict 
historical research has revealed that the long-standing practice of criminalizing sodomy that played such an important role in Bowers was directed at the conduct involved rather than the gender of the participants; there simply is no persuasive historical support for the claim that the American legal tradition countenances the punishment of homosexual intimacy because it occurs between persons of the same sex. ${ }^{200}$ What was only a subtext in Bowers, the constitutionality of a state using sodomy laws selectively to harass gays and lesbians, is now the principal legal question before the Court.

Finally, it is of no small consequence that Lawrence will be decided nearly twenty years after Bowers. First, there has been a dramatic shift in state criminal statutes. Of the thirteen states that continue to criminalize sodomy, nine have statutes that bar consensual sodomy for all couples, while only two states have explicitly limited their sodomy statute to same-sex couples. ${ }^{201}$ Moreover, the courts in a number of states have invalidated sodomy statutes for violating state constitutional guarantees. ${ }^{202}$

short-term or shortsighted deviations from wiedely held social norms; it has an important backward looking dimension. For purposes of due process, the baseline for inquiry has tended to be the common law, Anglo American practice, or the status quo. ... Thus, in Bowers, the Court declined to find, as respondent requested, a fundamental right to engage in homosexual sodomy because sodomy was not a fundamental liberty that was deeply rooted in this Nation's history and tradition.

The Equal Protection Clause, on the other hand, has served an entirely different set of purposes from the Due Process Clause. That clause ... was consciously designed to eliminate practices that existed at the time of ratification and that were expected to endure. The function of the Equal Protection Clause is to protect disadvantaged groups against the effects of past and present discrimination by political majorities. It is not rooted in common law or status quo baselines or in Anglo-American conventions. The baseline is instead a principle of equality that operates as a criticism of existing practice.

Id. at 377 n.12 (Anderson, J., dissenting).

200 At the time of the ratification of the Fourteenth Amendment, most states criminalized sodomy as conduct that was not grounded in the gender of the persons involved, and although three states did limit sodomy to conduct between men, no state defined sodomy in terms of conduct between same-sex couples generally. See Anne B. Goldstein, History, Homosexuality, and Political Values: Searching for the Hidden Determinants of Bowers v. Hardwick, 97 YALE L.J. 1073, 1082-84 (1988). Goldstein emphasizes that, notwithstanding the rhetorical invocations of a time-honored moral approbation of homosexuality, Bowers was premised on much more recent constructions of homosexuality as an evil to be avoided. "Even [the Justices'] apparently uncontroversial assumption that lovemaking between persons of the same sex has always been seen as fundamentally different from heterosexual lovemaking is incorrect: This distinction turns out to be more modern than either the Bill of Rights or the Fourteenth Amendment." Id. at 1074-75.

${ }^{201}$ Petition for Writ of Certiorari, supra note 197, at 4.

202 See, e.g., Jegley v. Picado, 80 S.W.3d 332 (Ark. 2002) (holding that the Arkansas sodomy statute infringes on the implicit right to privacy in the state constitution). The Jegley court noted that nine other states have invalidated sodomy laws by judicial decision, 
Additionally, the Supreme Court's decision in Romer has obviously shaped the manner in which the Equal Protection challenge in Lawrence will fare. ${ }^{203}$ Finally, changing public perceptions about gays and lesbians undoubtedly will play a role, even if this role is not explained by the Justices. ${ }^{204}$ To summarize by paraphrasing Chief Justice Warren, there is no way to turn back the clock for purposes of constitutional adjudication, even if only to 1986. Despite Justice Scalia's protest against "those who think that the Constitution changes to suit current fashions," 205 there can be no doubt that Lawrence will be decided in an entirely different context than Bowers, and that this change will be significant. In some respects, Lawrence primarily represents a battle between the legacy of Bowers and the legacy of Romer, and so this case could arise only at this moment in our constitutional history. The Court can easily reach a decision in Lawrence that preserves a role for both precedents, but the petitioners are arguing that the Court ought to overrule Bowers in light of Romer and other

including the state of Georgia. Id. at 345 n. 4 . There is a legitimate argument that these uses of state constitutions do not represent a genuine "constitutional" discourse at the state level. See James A. Gardner, The Failed Discourse of State Constitutionalism, 90 MICH. L. REV. 761 (1992). It seems clear that these state court decisions represent dissenting views about the constitutional structure of American civic life generally. Gardner subsequently criticized the "states-as-laboratories" metaphor as it is used to justify this manner of state constitutional practice. "The Supreme Court may learn something from watching the state court go about its business, but it is no part of that business to assist the Supreme Court to perform its very different function." James A Gardner, The "States-as-Laboratories" Metaphor in State Constitutional Law, 30 VAL. U. L. REV. 475, 490-91 (1996). Gardner's conclusion may well be justified under a positivist, hierarchical model of constitutional governance, but in fact this is precisely the role that the state courts are playing as highly respected rhetorical agents, and it will be part of the rhetorical reality that will shape the Supreme Court's adjudication in Lawrence. In his most recent article, Gardner now accepts a more "functionalist" account of the rhetorical importance of state constitutional adjudication for ongoing constitutional discourse at the national level. See James A. Gardner, State Constitutional Rights as Resistance to National Power: Toward a Function Theory of State Constitutions, 37 GEO. L. REV. (forthcoming 2003) (recognizing that "state judicial rejection of and divergence from purportedly incorrect or abusive Supreme Court precedents concerning the scope of individual rights helps check national power" in part by contributing "to the establishment of a nationwide legal consensus at the state level, a factor which the Supreme Court sometimes considers in the course of its own constitutional decision making") (manuscript on file with author). I thank Jim Gardner for continuing our long-standing conversation about these matters, and for his helpful comments on this footnote.

${ }^{203}$ See Petition for Writ of Certiorari, supra note 197, at 17 (arguing that the Supreme Court must act to correct the mistaken conclusion by the Texas Court of Appeals that Romer is limited to its factual context).

${ }^{204}$ The Petition argued that since the Bowers decision, "the country has developed a more accurate understanding of gay and lesbian couples and families," implicitly suggesting that the Judges too might no longer be working from the same prejudices and misunderstandings. Id. at 28.

${ }^{205}$ Romer v. Evans, 517 U.S. 620, 640-41 (1996) (Scalia, J., dissenting). 
developments. ${ }^{206}$ Both hermeneutical appropriation and Nietzschean critique are at work in this complex setting.

These Supreme Court cases demonstrate that interesting legal disputes require more than simple inferences within a doctrinal conceptual framework, but also that the "real question at issue" can't be abstracted from these contexts altogether. Critical insight is possible because legal reasoning is instantiated within, but always re-shaping, doctrinal traditions. In their own ways, both Gadamer and Nietzsche emphasize the critical potential of tradition. Legal practice, as exemplified in the cases under discussion, gains critical purchase in the rhetorical developments that are made possible by the resources of tradition. Justice Scalia offers what might appear at first glance to be a Nietzschean critique, cutting through surface appearances to the clash of political power that subtends the doctrinal squabbles. But in fact his approach runs contrary to my model of critical insight. First, he attempts to sharply divide the political battle of wills from reasoned legal argumentation, when no such division is possible. The doctrinal disputes bear within them the many underlying political issues, and therefore are no less rhetorical and hermeneutical than political disputes. Seen from the opposite angle, he presumes that political battle is purely a question of brute power, when in fact power is exercised rhetorically and hermeneutically, which is to say that it is exercised in part through the doctrinal traditions that hold their own prejudicial power.

If Justice Scalia does not fit the role of Nietzschean critic (a comforting thought for him, we can be sure), how does one approach these cases with the kind of critical energy that Nietzsche unleashed against Christianity and moral philosophy? When Justice Stevens declares that the Court is reinscribing homophobic beliefs under the pretense of neutral constitutional decisionmaking, ${ }^{207}$ is he playing the role of Nietzsche declaring that God is dead? In some respects, the answer is yes, although, like Nietzsche, Justice Stevens will have to wait to see if his announcement of an event that already has taken place is verified in social life. This critical posture cannot be separated from the rhetorical and hermeneutical elaboration of tradition, which is more closely associated with Gadamer's philosophy, but it works from the tradition in a different manner. Justice Stevens builds on converging doctrinal principles to conclude that we already no longer believe that gays and lesbians can be treated as second-class citizens, even if we have not yet completely acknowledged this

\footnotetext{
${ }^{206}$ Petition for Writ of Certiorari, supra note 197, at 22-30.

207 See supra notes 185 and 188.
} 
fact. The homophobic "God" is dead, but it is we who have killed him with our ongoing practices. The Nietzschean claim does not rest on a timeless absolute, but rather on a philosophical naturalism that regards human nature as deeply interpretive. Vattimo's weak thought espouses just this approach to Nietzschean critique: we always are in a position to claim only that we are interpreting our provenance, which means that we must be ready to abandon our current beliefs in favor of a better interpretation, but also rejects the notion that we can claim recourse to an invariant standard by which to judge interpretations. ${ }^{208}$ Where Justice Scalia sees a seething clash of power-interests that is outside the realm of legal thinking, Justice Stevens finds an event that must be announced: the overcoming of outmoded beliefs through the re-working of traditional beliefs. ${ }^{209}$

In these three cases we find the rhetorical character of legal reasoning, the critical power of tradition, and the potential for Nietzschean critique as a Verwindung within a cultural moment. And the story continues with the Lawrence case, which shows that even the power of discretionary review cannot insulate the Court from legal dynamism. Legal scholars, removed from the immediate field of play, too often lose sight of this critical dimension of legal practice and fall back on claims grounded in an invariant truth. Whether this "truth" is textual plain meaning, neo-Marxist economics, political liberalism, or psychoanalytic theory is beside the point. Legal scholars can tap into the source

\footnotetext{
208 VATTIMO, AFTER CHRISTIANITY, supra note 136, at 51.

209 Another example of this kind of announcement occurs repeatedly in the Court's death penalty jurisprudence. In Callins v. Collins, 510 U.S. 1141 (1994) (den. cert.), Justice Blackmun offered a particularly dramatic critique by stating: "From this day forward, I shall no longer tinker with the machinery of death." Id. at 1145 (Blackmun, J., dissenting). Blackmun rehearses the development of the Court's intricate case law, juxtaposing his personal beliefs against the death penalty and his efforts over a twenty year period to work through the doctrine in a reasonable manner. In the end, he concludes, the doctrinal paths are impassable and compel the conclusion that the death penalty simply cannot be administered in a just and fair manner that also precludes arbitrariness, and therefore is in all cases unconstitutional. Justice Blackmun's doctrinal journey provides another example of the critical potential of working through a tradition, and also the Nietzschean posture of declaring that the tradition has out-lived its usefulness and must be carried on in a new manner. The point is that Blackmun's critical perspective does not come from a truthful perspective outside a useless tradition of legal argumentation, but emerges from the argumentation. Like Nietzsche, though, if Justice Blackmun's critique proves to be accurate in this case it will do so only posthumously.

Justice Scalia, concurring in the denial of certiorari, wrote in response to agree that the Court's jurisprudence is impossible, but to respond to this situation by leaving the question to legislatures and juries. Id. at 1141-43 (Scalia, J., concurring). Again, he attempts to divest law of political dimensions, and to divest politics of legal dimensions, in an attempt to avoid (or at least push over to another realm) the uncertainty that flows from the hermeneutical and rhetorical character of reasoning.
} 
of critique by recognizing that the model of critical hermeneutics leads them to an engagement with practice. Nietzsche announced the destruction of Christianity from within; critical legal theorists face the same task. Without a guarantee or even firm guideposts, critical legal theorists can move forward most productively by looking to the examples of Gadamer and Nietzsche. Within the play of their differences lies the recognition of legal critique, which is always at once an experience and a provocation. 